Article

\title{
Self-Sustaining Thorium Boiling Water Reactors
}

\author{
Francesco Ganda ${ }^{1,2}$, Francisco J. Arias ${ }^{1,3}$, Jasmina Vujic ${ }^{1}$ and Ehud Greenspan ${ }^{1, *}$
}

1 University of California, Department of Nuclear Engineering, Berkeley, CA 94720, USA;

E-Mails: francesco.ganda@inl.gov (F.G.); frarias@mit.edu (F.J.A.); vujic@nuc.berkeley.edu (J.V.)

Idaho National Laboratory, 2525 Fremont Avenue, Idaho Falls, 83404, ID, USA

3 MIT Department of Nuclear Science and Engineering, Center for Advanced Nuclear Energy Systems (CANES), 77 Massachusetts Avenue, Cambridge, MA, 02139, USA

* Author to whom correspondence should be addressed; E-Mail: gehud@nuc.berkeley.edu; Tel.: +1-510-643-9983; Fax: +1-510-643-9685.

Received: 14 August 2012; in revised form: 14 September 2012 / Accepted: 17 September 2012 / Published: 1 October 2012

\begin{abstract}
A thorium-fueled water-cooled reactor core design approach that features a radially uniform composition of fuel rods in stationary fuel assembly and is fuel-self-sustaining is described. This core design concept is similar to the Reduced moderation Boiling Water Reactor (RBWR) proposed by Hitachi to fit within an ABWR pressure vessel, with the following exceptions: use of thorium instead of depleted uranium for the fertile fuel; elimination of the internal blanket; and elimination of absorbers from the axial reflectors, while increasing the length of the fissile zone. The preliminary analysis indicates that it is feasible to design such cores to be fuel-self-sustaining and to have a comfortably low peak linear heat generation rate when operating at the nominal ABWR power level of nearly $4000 \mathrm{MW}_{\text {th }}$. However, the void reactivity feedback tends to be too negative, making it difficult to have sufficient shutdown reactivity margin at cold zero power condition. An addition of a small amount of plutonium from LWR used nuclear fuel was found effective in reducing the magnitude of the negative void reactivity effect and enables attaining adequate shutdown reactivity margin; it also flattens the axial power distribution. The resulting design concept offers an efficient incineration of the LWR generated plutonium in addition to effective utilization of thorium. Additional R\&D is required in order to arrive at a reliable practical and safe design.
\end{abstract}

Keywords: thorium; fuel-self-sustaining; RBWR; ABWR 


\section{Introduction}

Recently, Hitachi developed a fuel-self-sustaining reduced moderation Boiling Water Reactor (BWR) core design that features a breeding ratio slightly above 1.0 when using depleted uranium for the makeup fuel; it is referred to as the RBWR-AC in which the "R" stands for "Resource Renewable" [1,2]. The discharged fuel is reprocessed to remove fission products and all the trans-uranium elements (TRU) are recycled back to the core along with the uranium. The RBWR-AC core can fit within the pressure vessel of the well proven Advanced BWR (ABWR) and deliver the same total power as the ABWR. Hence, the specific capital cost of the RBWR-AC is expected to be smaller than that of the presently available Sodium cooled Fast Reactor (SFR) core designs. Furthermore, it is reasonable to expect the RBWR-AC to have other cost advantages over the SFR because the Light Water Reactor (LWR) infrastructure required for RBWR-AC deployment is mostly in place and the utilities have extended experience in operating and maintaining light-water cooled reactors. On the other hand, the fuel cycle cost of the RBWR-AC is expected to be higher than that of the SFR because the discharge burnup of the RBWR is estimated to be only about half that of the SFR [2].

Relative to conventional BWR (and ABWR), the RBWR-AC core design features a tighter fuel lattice, a shorter core, a smaller coolant mass flow-rate and pressure drop and a higher core void fraction. Figure 1 shows the core layout of the RBWR-AC while Table 1 compares selected design and performance characteristics of the RBWR-AC with the ABWR. The core average void fraction in the RBWR-AC is about $60 \%$ (closer to $65 \%$ in more recent designs) compared to about $36 \%$ in the ABWR (Figure 2). The figures and table do not pertain to the latest designs but are representative; they are taken from open publications [1,2].

Figure 1. Resource-Renewable Boiling Water Reactor (RBWR)-AC core layout (Note: fissile fuel is TRU, not $\mathrm{Pu}$ ) [1].
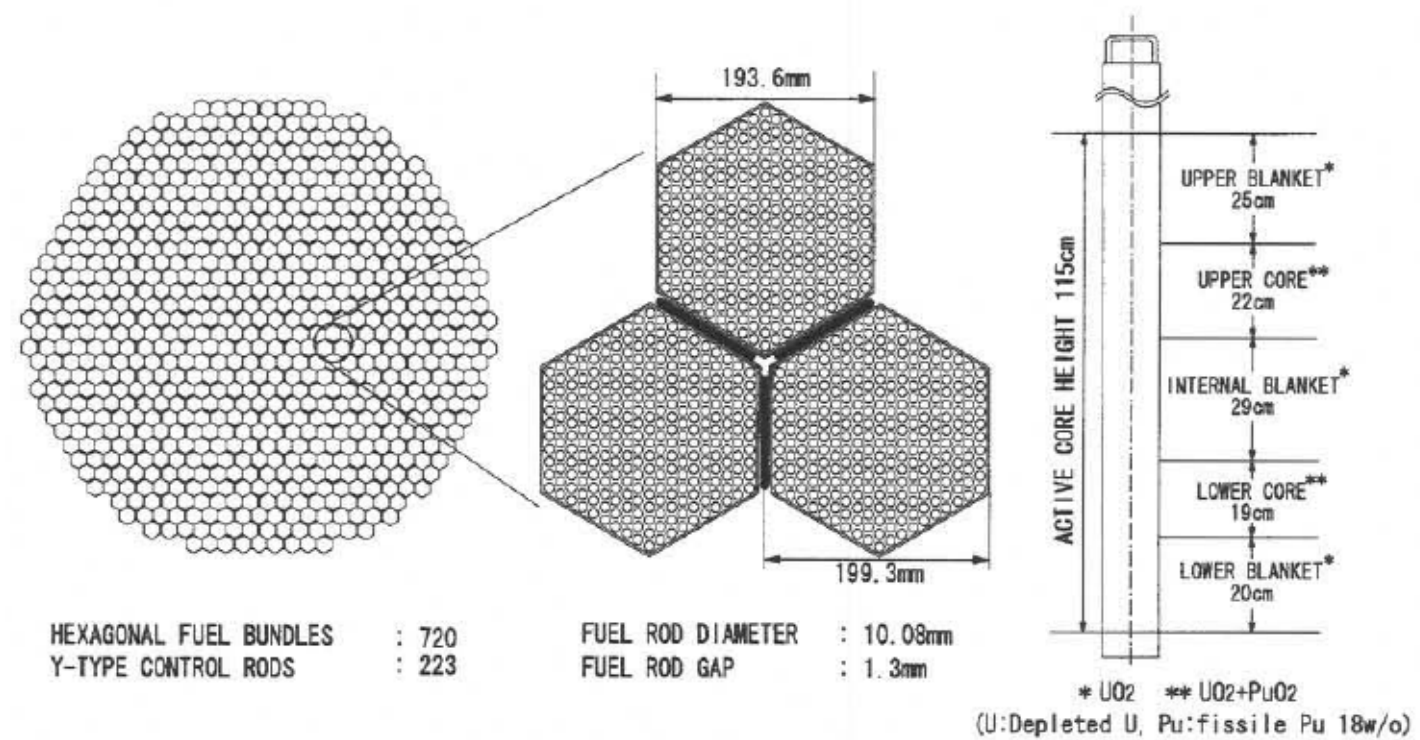

(a) CORE ARRANGEMENT

(b) FUEL BUNDLES AND Y-TYPE CONTORL ROD

(c) FUEL BUNDLE 
Table 1. Comparison of performance characteristics of the fuel-self-sustaining RBWR-AC and Advanced BWR (ABWR) [1].

\begin{tabular}{lclc}
\hline Item & RBWR-AC & Item & ABWR \\
\hline Thermal power, MWt & 3926 & Thermal power, MWt & 3926 \\
Electrical power, MWe & 1356 & Electrical power, MWe & 1356 \\
Number of fuel bundles & 720 & Number of fuel bundles & 872 \\
Core height, mm & 1200 & Core height, mm & 3710 \\
Core configuration & Parfait & & \\
Coolant mass flow rate, kt/h & 22 & Coolant mass flow rate, kt/h & 58 \\
Core exit quality, \% & 41 & Core exit quality, \% & 13 \\
Core exit void fraction, \% & 60 & Core exit void fraction, $\%$ & 36 \\
Core pressure drop, MPa & 0.11 & Core pressure drop, MPa & 0.21 \\
HM inventory, t & 131 & HM inventory, t & 151 \\
Fissile Pu/HM in fissile zones, wt \% & 18 & Uranium enrichment, \% & 3.8 \\
Fissile Pu inventory, t & 8.9 & & 45 \\
Burnup, GWd/tHM & 45 & Burnup, GWd/tHM & 12 \\
MLHGR, kW/ft & 14.4 & MLHGR, kW/ft & 1.3 \\
MCPR & 1.3 & MCPR & \\
\hline
\end{tabular}

Figure 2. Axial distribution of coolant volume fraction in the RBWR-AC as compared to the ABWR [1].

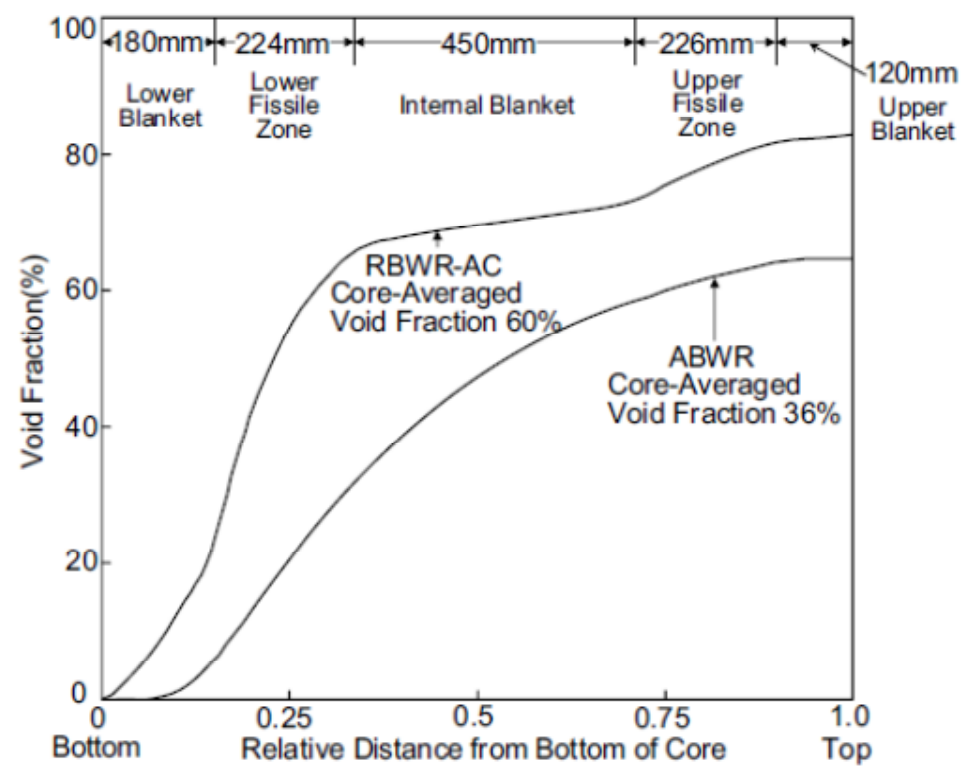

The significantly smaller hydrogen-to-Heavy-Metal (HM) atom ratio and the high TRU loading makes the RBWR-AC spectrum quite hard. The neutron spectrum of the RBWR-AC is compared to the PWR and a BR =1.0 SFR in Figure 3. As indicated, the spectrum of the RBWR-AC is closer to that of a typical liquid metal cooled fast reactor (ARR in the figure) than it is to the spectrum of a conventional $\mathrm{UO}_{2}$ fueled PWR. The RBWR-AC spectrum features a larger component of $\mathrm{MeV}$ 
neutrons and a larger component of epithermal neutrons than the SFR spectrum. The larger fraction of $>1 \mathrm{MeV}$ neutrons is due to the sharp drop of the energy-dependent hydrogen scattering cross section in this energy range. The hard spectrum of the RBWR-AC makes it possible to achieve a conversion ratio slightly higher than unity, which is similar to that of the ARR.

Figure 3. RBWR-AC, Pressurized Water Reactor (PWR) and Advanced Recycling Reactor (ARR) neutron spectrum [2].

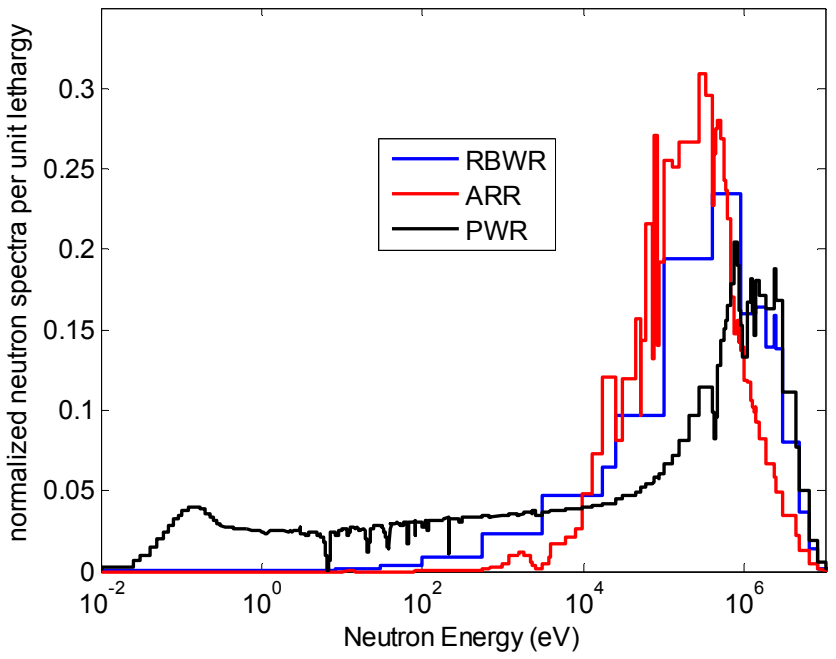

However, the achievement of negative void reactivity coefficients in the RBWR-AC is very challenging because of the large increase, with coolant voiding induced spectrum hardening, in the $\eta$ values of most of the TRU isotopes as well as of the ${ }^{238} \mathrm{U}$. To counteract that effect the coolant voiding has to substantially enhance the leakage probability of neutrons out from the fissile zones. (SFR cores usually feature positive void coefficient of reactivity which is compensated by, in addition to the fuel Doppler effect, the fuel axial expansion and core radial expansion-mechanisms that are not applicable in BWR type reactors using oxide fuel. The SFR power coefficient of reactivity is negative). The need for a large leakage-probability drove Hitachi to design a pancake shape small height core, to "lump" the fissile fuel into two axial zones, each approximately $20 \mathrm{~cm}$ in length, with depleted U blanket zones on both sides of each fissile zone, and to add $\mathrm{B}_{4} \mathrm{C}$ to the bottom and top reflectors. The resulting axial power distribution is quite sensitive to the TRU loading in the two axial fissile zones, to the Pu buildup in the three blanket zones surrounding the two fissile zones, to the axial void distribution, to the location and amount of boron in the reflectors and to the control rods insertion pattern.

In a recent EPRI-sponsored study, a team of researchers from the University of Michigan, MIT and the University of California at Berkeley performed an independent evaluation of the Hitachi RBWR-AC core design using largely independent computational methods [2]. The independent evaluation concluded that the equilibrium-cycle breeding ratio is slightly above 1.0, thus providing for a self-sustaining fuel cycle in which depleted uranium is used for the makeup fuel. The fuel and power coefficients of reactivity were found to be negative under both beginning of equilibrium cycle and end of equilibrium cycle conditions. However, there is considerable uncertainty in the calculated void coefficient of reactivity, and it is not certain that the void coefficient is negative at all times, 
as presently required for BWR. The team has also expressed concerns that the Hitachi RBWR-AC core design may not have adequate thermal safety margin. In general the current Hitachi RBWR-AC design appears to be quite sensitive to small design variations and to perturbations in operating conditions, which could make it more difficult to for the RBWR-AC to meet the safety requirements for licensing than current BWRs. By slightly modifying the RBWR-AC core design, it may be possible to eliminate the concerns expressed above.

A different approach to the design of reduced moderation fuel-self-sustaining BWR cores that is based on the major ingredients of the Hitachi RBWR-AC core design has been recently proposed $[3,4]$. The objective of the present paper is to describe this alternative RBWR-AC design approach and to summarize results obtained from a very preliminary feasibility study. The differences between the proposed approach and the Hitachi design include: use of thorium instead of depleted uranium, elimination of the internal blanket and elimination of the $\mathrm{B}_{4} \mathrm{C}$ or other parasitic absorbers from the axial reflectors, while increasing the length of the fissile zone ("seed"). As ${ }^{232}$ Th has a significantly smaller fast fission cross section than ${ }^{238} \mathrm{U}$ and as the $\eta\left({ }^{233} \mathrm{U}\right)$ increase with neutron energy is significantly smaller than that of ${ }^{239} \mathrm{Pu}$ and most other TRU in the relevant high energy range, it is possible to design a Th-based high void fraction water cooled core to have negative void reactivity coefficients without having to design the seed to have as high a leakage probability.

Many studies of thorium fueled LWRs had been performed in the past; [5-13] is a very partial list of references. The closest to fuel-self-sustaining (breeding) designs arrived at in the past are the so called "seed-and blanket" designs in which the thorium and ${ }^{233} \mathrm{U}$ fuels were radially segregated - the ${ }^{233} \mathrm{U}$ fuel was loaded into "seed" fuel rods and/or fuel assemblies and most of the thorium was loaded into "blanket" fuel rods and/or fuel assemblies. In the Shippingport reactor [5,6] that demonstrated fuel-self-sufficiency the seed fuel assemblies had to be axially moved out and into the core in order to achieve sustainability. In more recent seed-and-blanket Th-based LWR core designs, such as those reported in $[7,8]$, the radial segregation of seed and blanket results in power density mismatch that complicates the safety and fuel management. No such complications are needed for implementing the design presented in this work, which features radially uniform fuel rods and stationary fuel assemblies.

Section 2 describes the reference thorium-based RBWR core examined while Section 3 describes the methodology used for this preliminary feasibility study. The performance characteristics obtained for the reference core are summarized in Section 4 (the analysis of this core was performed by the first author). An alternative thorium-based core design and its calculated performance characteristics are described in Section 5 (the analysis of this core was performed by the second author). Section 6 discusses issues of concern that will have to be addressed in the future.

\section{Reference Core}

The core being considered in the present paper features the same tight lattice radial dimensions and the same outlet void condition of the Hitachi RBWR-AC that is based on the U-Pu fuel cycle [1,2]. The core can fit within the current ABWR pressure vessel. The primary differences, other than in the fuel and core designs, are in the reactor vessel internals and in the control rods design and location. As the thorium-breeder core is approximately $2 \mathrm{~m}$ shorter than that of the contemporary ABWR, it 
may be possible to reduce the reactor vessel length. It thus appears that the thorium-breeder BWR could be deployed in the relatively near-term at a cost similar to that of current ABWRs.

The reference core unit cell is composed of a $50 \mathrm{~cm}$ long bottom $\mathrm{ThO}_{2}$ blanket, a $110 \mathrm{~cm}$ long fissile zone made of a mixture of ${ }^{233} \mathrm{UO}_{2}$ and $\mathrm{ThO}_{2}$, and a $70 \mathrm{~cm}$ long upper $\mathrm{ThO}_{2}$ blanket illustrated in Figure 4. The fuel pellet diameter is $0.885 \mathrm{~cm}$ and the distance between the centers of the rods (or pitch), arranged in a hexagonal lattice, is $1.135 \mathrm{~cm}$. The $0.06 \mathrm{~cm}$ thick clad is made of Zircaloy. The inlet water density is $0.735 \mathrm{~g} / \mathrm{cm}^{3}$ and the water density at the exit is $0.087 \mathrm{~g} / \mathrm{cm}^{3}$; the coolant flow rate is adjusted to provide this coolant outlet density at the nominal core power level. The reference core power assumed is $4000 \mathrm{MW}_{\text {th }}$-similar to that of the Hitachi proposed RBWR design. The corresponding average fuel pin power is $20 \mathrm{KW}_{\text {th }}$; this value was assumed for the design analysis of our reference unit cell.

Figure 4. Reference thorium-breeder unit cell dimensions and Beginning-Of-Life (BOL) composition.
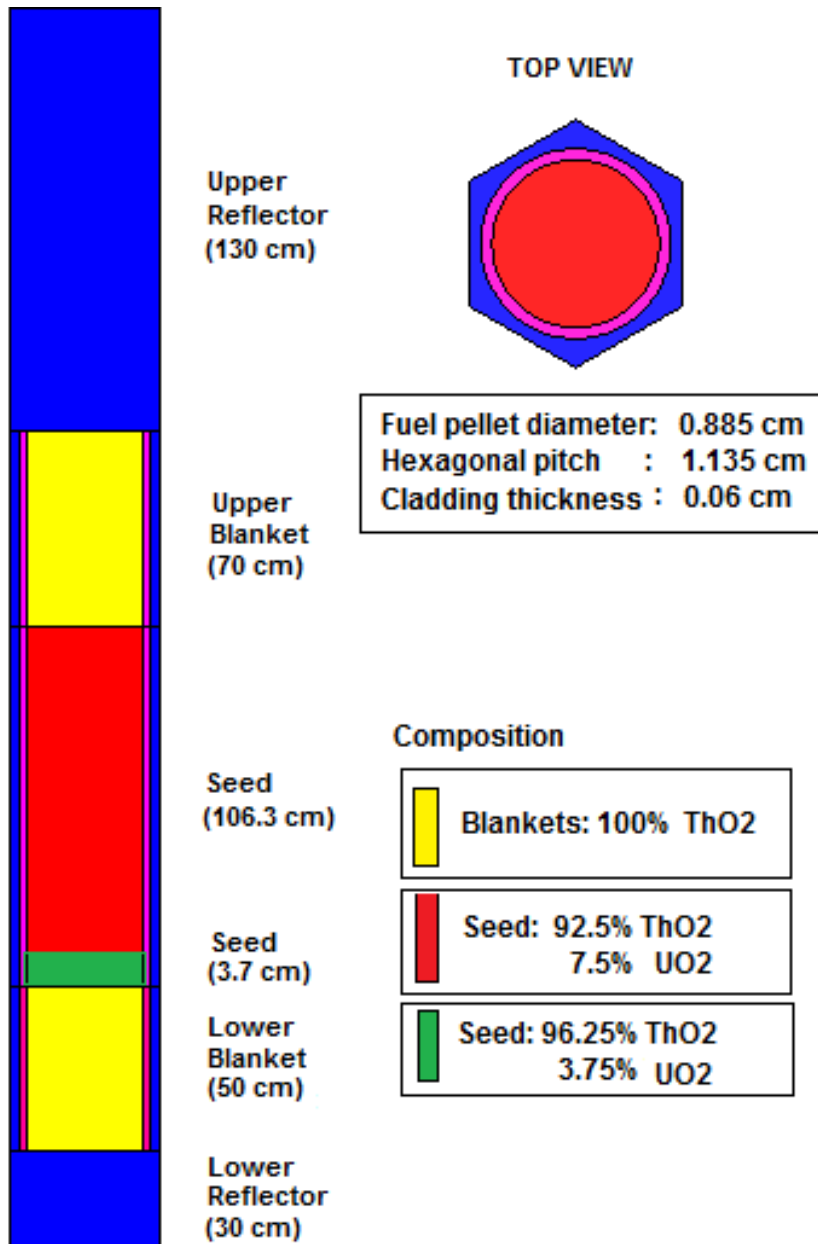

Blanket

Hexagonal pitch : $1.135 \mathrm{~cm}$

Cladding thickness : $0.06 \mathrm{~cm}$

$(70 \mathrm{~cm})$

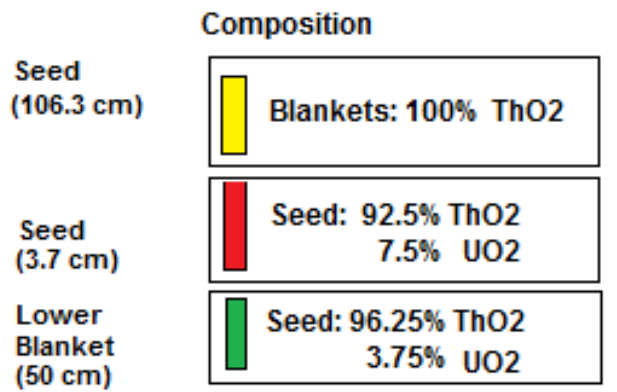

Lower

Reflector

$(30 \mathrm{~cm})$

The seed Heavy Metal (HM) composition in the initial core is assumed to be 7.5 atom $\%{ }^{233} \mathrm{U}$ and 92.5 atom\% Th. To reduce the Beginning-Of-Life (BOL) power spiking at close proximity to the bottom blanket region - in which the water is at its liquid density - the bottom $3.7 \mathrm{~cm}$ of the fissile zone is loaded with 3.75 weight $\%$ - half the amount of ${ }^{233} \mathrm{U}$ than in the rest of the fissile zone. It is also 
assumed that, similarly to the Hitachi RBWR, the core has 5 fuel batches and that the radial leakage probability from the $\sim 7.5 \mathrm{~m}$ in diameter core is $2.5 \%$. (This value is larger than the $1 \%$ inferred from a 3-D RBWR-AC core analysis [2] so as to be on the conservative side). The above specifications are, by no means, the optimal; they are used only for assessing the feasibility of attaining a fuel-selfsustaining design that meets the major design constraints.

\section{Methodology}

The preliminary feasibility studies presented in this work are based on a 3-D unit cell analysis. The computations are performed with the SCALE code system using TRITON for the driver code, the KENO-V Monte Carlo code for neutron transport calculation using ENDF/B-V derived 238 energy group cross-sections, and the ORIGEN-S code for burnup calculations. The multi-group KENO results of the neutronic characteristics were found consistent with point-energy MCNP results. The active fuel portion of the fuel pin is divided into fifty five axial depletion zones-10 in the lower blanket, 30 in the fissile area and 15 in the upper blanket.

The core performance is estimated from the single unit-cell burnup analysis assuming a 5-batch fuel-management scheme and the linear-reactivity model - the core average $k_{\text {eff }}$ is estimated from: $1 /\left(f_{1} / k_{\text {eff, } 1}+f_{2} / k_{\text {eff }, 2}+f_{3} / k_{\text {eff }, 3}+\ldots+f_{n} / k_{\text {eff,n }}\right)$ where $n$ is the number of batches the core is divided into, $k_{\text {eff,i }}$ is the $k_{\text {eff }}$ value calculated from the unit cell for batch $i$ (with axial leakage included), and $f_{i}$ is the fraction of the total core power generated by batch $i$. The value of $f_{i}$ can be determined from a 3-D analysis of a representative core; for the illustrations to follow it is assumed to be $1 / \mathrm{n}$. The criticality constraint is imposed by requiring that the core average end-of-cycle (EOC) $\mathrm{k}_{\text {eff }}$ has to be 1.025 - to account for the assumed 2.5\% radial neutron leakage probability (Section 2). The attainable discharge burnup is the burnup of the fuel discharged at the EOC from the $\mathrm{n}^{\text {th }}$ batch. Likewise, the core average reactivity is estimated from $\rho=\left(f_{1} \rho_{1}+f_{2} \rho_{2}+f_{3} \rho_{3}+\ldots f_{n} \rho_{n}\right)$ in which $\rho_{i}$ is the reactivity calculated for batch $i$. Although in the actual core the $f_{i}$ factors are batch-dependent, the Hitachi RBWR-AC radial power distribution is very flat; the peak-to-average radial power density is $\sim 1.25$ [2]. Results obtained for the RBWR-AC core using the simplified unit cell analysis described above were in reasonable agreement with results obtained [2] using detailed 3-D core calculations.

The axial zone-dependent water density is determined to be consistent with the axial power distribution by using a simple energy and mass-balance model [4]. Although rather approximate, the model captures the main physical phenomena by iterating between the axial power distribution and the axial water density distribution at each burnup step. Results more recently obtained using a more accurate drift-flux model confirm the conclusions reported in this paper that were derived using the mass-energy balance model.

\section{Reference Case Results}

Multi-recycling studies were performed to establish the equilibrium core composition and assess its neutronic performance. After each pass through the core, the fuel is cooled for 3 years and then reprocessed. All the actinides (up to ${ }^{248} \mathrm{Cm}$ ) are recycled and thorium oxide is added for makeup. Only $\mathrm{ThO}_{2}$ is loaded in the blankets. Reprocessing losses were ignored so as to obtain a theoretical upper bound on the Fissile Inventory Ratio (FIR). 
Figure 5 shows that the ${ }^{233} \mathrm{U}$ inventory increases rapidly in the first few recycles, in which the conversion ratio is larger than 1 , before saturating at around recycle $\# 15$. The larger mass of ${ }^{233} \mathrm{U}$ increases the value of $k_{\text {eff }}$ with the number of recycles as shown in Figure 6 . After 7-8 recycles, $k_{\text {eff }}$ gets close to the equilibrium core value. Since $\mathrm{k}_{\mathrm{eff}}$ at the end of equilibrium cycle is larger than the design goal of 1.025 , the cycle length could be extended or the core could be operated with a breeding gain: upon fuel recycling a fraction of the uranium (and, possibly, all trans-thorium actinides) would be removed so as to reduce the BOEC $\mathrm{k}_{\text {eff }}$ to the level that would result in an EOEC $\mathrm{k}_{\text {eff }}$ of 1.025. It should be realized, though, that in the real core the breeding ratio will be somewhat smaller than the one predicted from our single pin analysis, since there will be some fuel loss in the recycling/refabrication processes and neutron losses to radial leakage and to parasitic absorption in the control elements.

Figure 5. Evolution of ${ }^{233} \mathrm{U}$ and of total uranium mass per fuel pin.

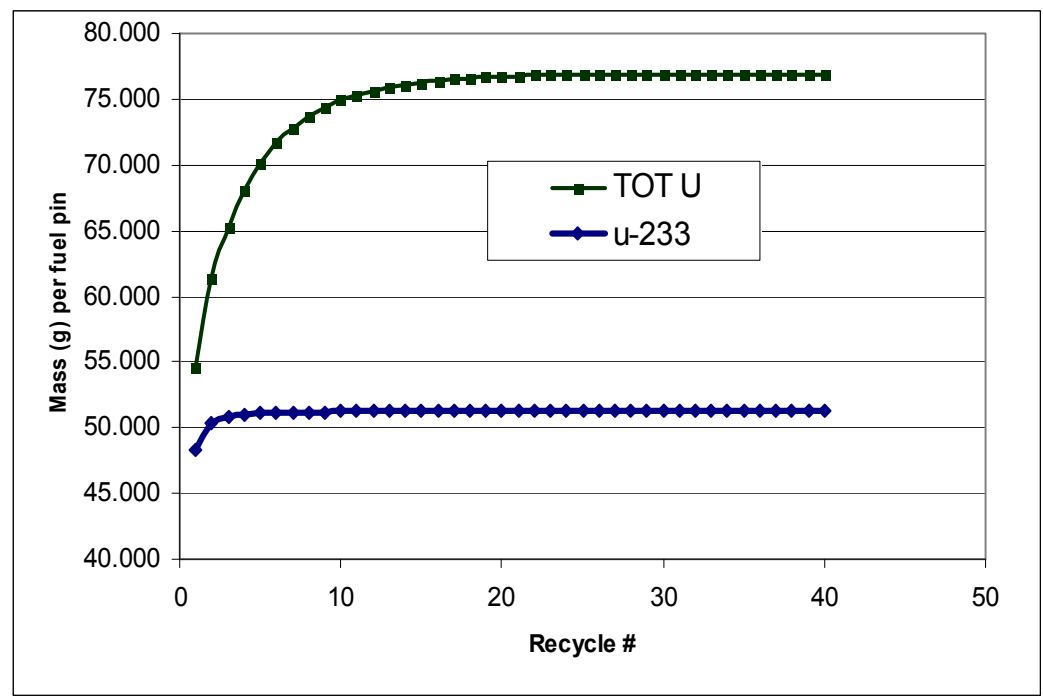

Figure 6. Evolution of the unit cell $\mathrm{k}_{\mathrm{eff}}$ for the first seven recycles along the fuel residence time (i.e., from loading in the 1 st batch to discharge after the 5 th batch).

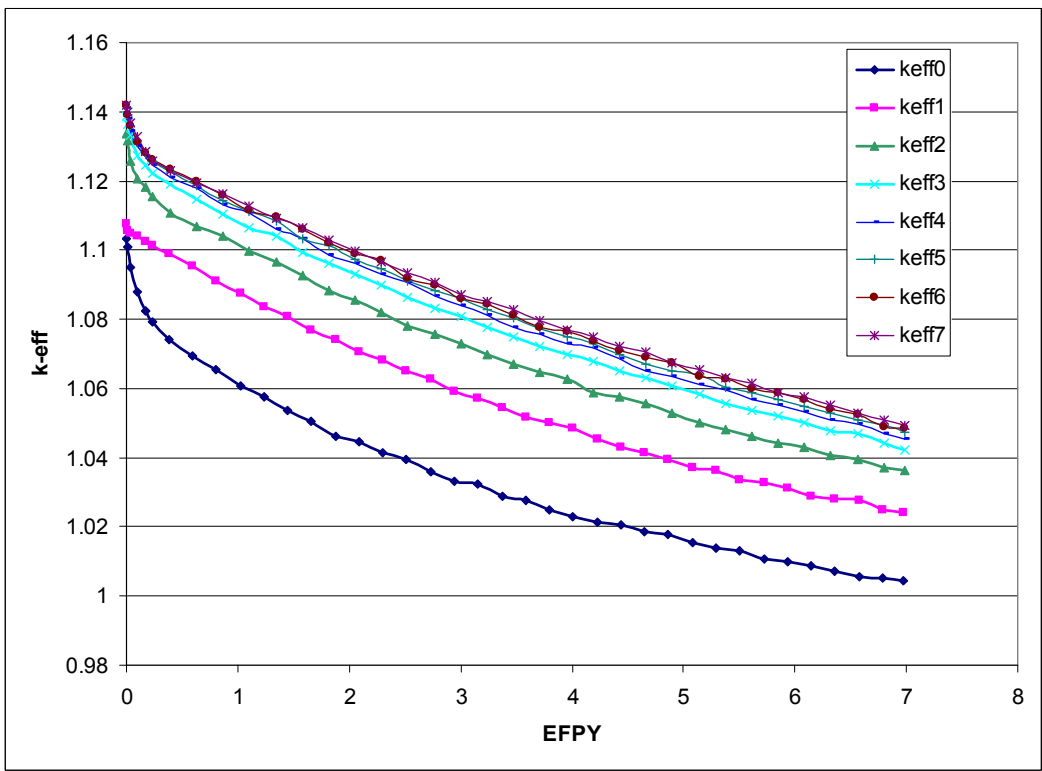


The primary conclusion from this preliminary analysis is that the neutron economy of the proposed system enables breeding. In the illustration provided in Section 5 the EOEC $\mathrm{k}_{\text {eff }}$ is indeed, 1.025 and the system is fuel-self-sustaining.

Figure 7 shows the equilibrium concentration of the actinides other than $\mathrm{U}$ and ${ }^{232} \mathrm{Th}$; i.e. of $\mathrm{Np}, \mathrm{Pu}$, $\mathrm{Am}, \mathrm{Cm}, \mathrm{Pa}$ and ${ }^{230} \mathrm{Th}$, as a fraction of the total HM mass. The equilibrium concentration of these actinides, to be referred to as Minor Actinides (MA), is $0.31 \%$; it is reached after about 40 recycles. The evolution of the inventories of $\mathrm{Pu}, \mathrm{Am}$ and $\mathrm{Cm}$ in the average fuel pin, relative to their equilibrium value, is shown in Figure 8. As expected, each isotope reaches saturation after its predecessor does.

Figure 7. Minor actinides concentration evolution as a fraction of total heavy-metal (HM).

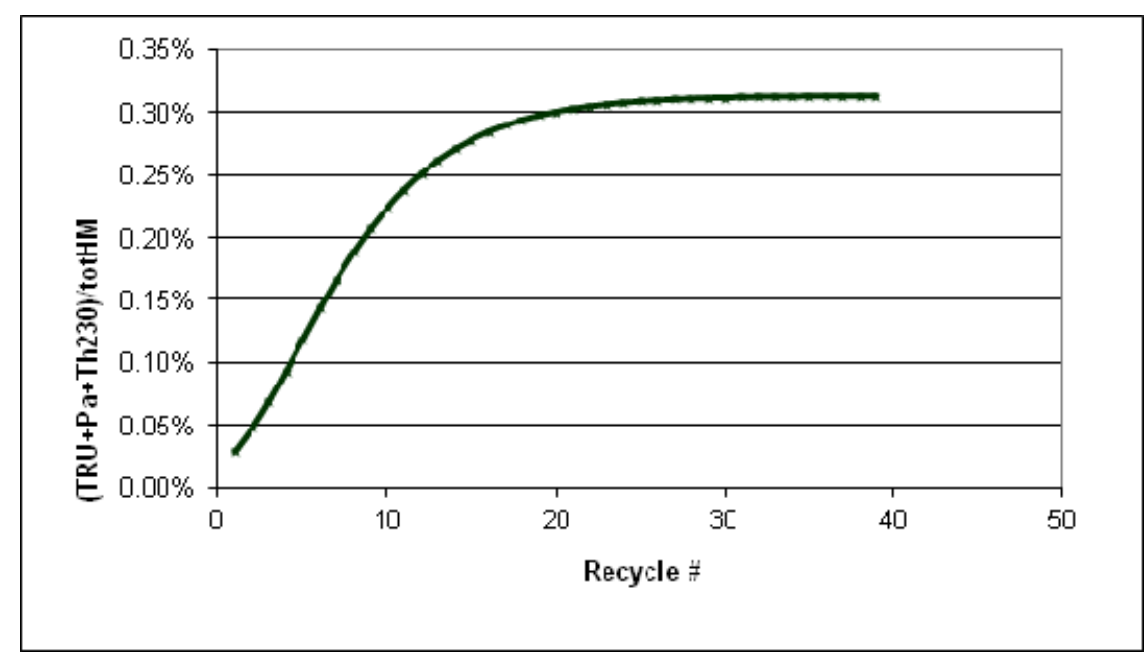

Figure 8. Buildup of $\mathrm{Pu}, \mathrm{Am}$ and $\mathrm{Cm}$ inventory.

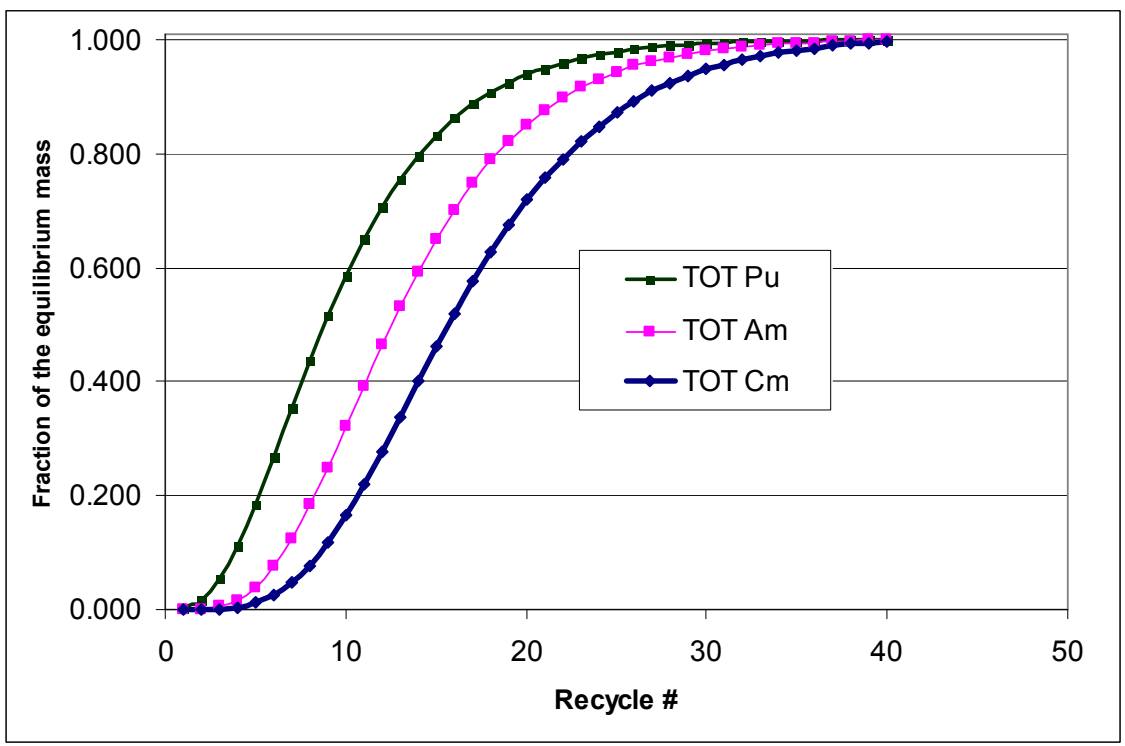

Table 2 gives the heavy metal composition in a fuel pin, including blanket zones, that is discharged from the equilibrium cycle and cooled for 3 years. The equilibrium composition in the loaded fuel pin can be inferred from the table data assuming that all the HM elements, except thorium, are loaded into the seed that makes $110 / 230$ of the fuel pin volume and that $54 \mathrm{gm}$ of thorium is added for makeup. 
Table 2. Heavy metal composition in a fuel pin discharged from the equilibrium core.

\begin{tabular}{ccc}
\hline Isotope & Mass per pin (gm) & Weight \% of HM \\
\hline Th-230 & 0.0386 & 0.0034 \\
Th-232 & 1065.0412 & 92.9738 \\
Pa-231 & 0.3018 & 0.0263 \\
$\mathrm{U}-232$ & 0.2706 & 0.0236 \\
$\mathrm{U}-233$ & 51.3227 & 4.4803 \\
$\mathrm{U}-234$ & 16.1287 & 1.4080 \\
$\mathrm{U}-235$ & 4.7991 & 0.4189 \\
$\mathrm{U}-236$ & 4.3508 & 0.3798 \\
$\mathrm{U}-238$ & 0.0309 & 0.0027 \\
$\mathrm{~Np}-237$ & 1.2277 & 0.1072 \\
$\mathrm{Pu}-238$ & 1.2657 & 0.1105 \\
$\mathrm{Pu}-239$ & 0.3889 & 0.0339 \\
$\mathrm{Pu}-240$ & 0.1556 & 0.0136 \\
$\mathrm{Pu}-241$ & 0.0620 & 0.0054 \\
$\mathrm{Pu}-242$ & 0.0408 & 0.0036 \\
$\mathrm{Am}-241$ & 0.0419 & 0.0036 \\
$\mathrm{Am}-242 \mathrm{~m}$ & 0.0013 & 0.0001 \\
$\mathrm{Am}-243$ & 0.0261 & 0.0023 \\
$\mathrm{Cm}-244$ & 0.0176 & 0.0015 \\
$\mathrm{Cm}-245$ & 0.0094 & 0.0008 \\
$\mathrm{Cm}-246$ & 0.0056 & 0.0005 \\
$\mathrm{Cm}-247$ & 0.0010 & $8.63 \mathrm{E}-05$ \\
$\mathrm{Cm}-248$ & 0.0005 & $3.95 \mathrm{E}-05$ \\
Total & 1145.5284 & 100.00 \\
$\mathrm{Makeup} \mathrm{Th}$ & 54.1705 & 4.515 \\
\hline
\end{tabular}

Figure 9 shows a comparison of the mass of the transmutation products of ${ }^{232} \mathrm{Th}$ and ${ }^{233} \mathrm{U}$ that are downloaded after the 1st recycle and at the equilibrium recycle. It is observed that at the 1st recycle the vast majority of transmutation products is made of ${ }^{231} \mathrm{~Pa}$, followed by ${ }^{237} \mathrm{~Np}$ and $\mathrm{Pu}-$ mostly ${ }^{238} \mathrm{Pu}$ (see Figure 10) and ${ }^{230} \mathrm{Th}$. At equilibrium the most abundant transmutation product is $\mathrm{Pu}-$ mostly ${ }^{238} \mathrm{Pu}$ (Figure 11), followed by ${ }^{237} \mathrm{~Np}$ and ${ }^{231} \mathrm{~Pa}$. The mass of ${ }^{230} \mathrm{Th}$ at equilibrium is similar to the mass of $\mathrm{Cm}$.

The equilibrium isotopic composition of $\mathrm{Am}$ and $\mathrm{Cm}$ is shown in Figure 12 and Figure 13, respectively. The Am is made primarily of ${ }^{241} \mathrm{Am}$ followed by ${ }^{243} \mathrm{Am}$, while ${ }^{242 \mathrm{~m}} \mathrm{Am}$ is present only in a relatively small amount. ${ }^{244} \mathrm{Cm}$ is the most abundant $\mathrm{Cm}$ isotope, followed by $\mathrm{Cm}$ isotopes in order of increasing mass. Figure 14 shows the isotopic composition of uranium, excluding ${ }^{233} \mathrm{U}$, after the $1 \mathrm{st}$ recycle and at equilibrium. In both cases the most abundant isotope is ${ }^{234} \mathrm{U}$, followed by ${ }^{235} \mathrm{U}$. At equilibrium, ${ }^{236} \mathrm{U}$ is present in a similar amount to ${ }^{235} \mathrm{U}$, while ${ }^{238} \mathrm{U}$ and ${ }^{232} \mathrm{U}$ constitute a negligible fraction of the total $\mathrm{U}$ mass. 
Figure 9. Total mass of Minor Actinides (MA) per fuel pin after the 1st recycle and at equilibrium.

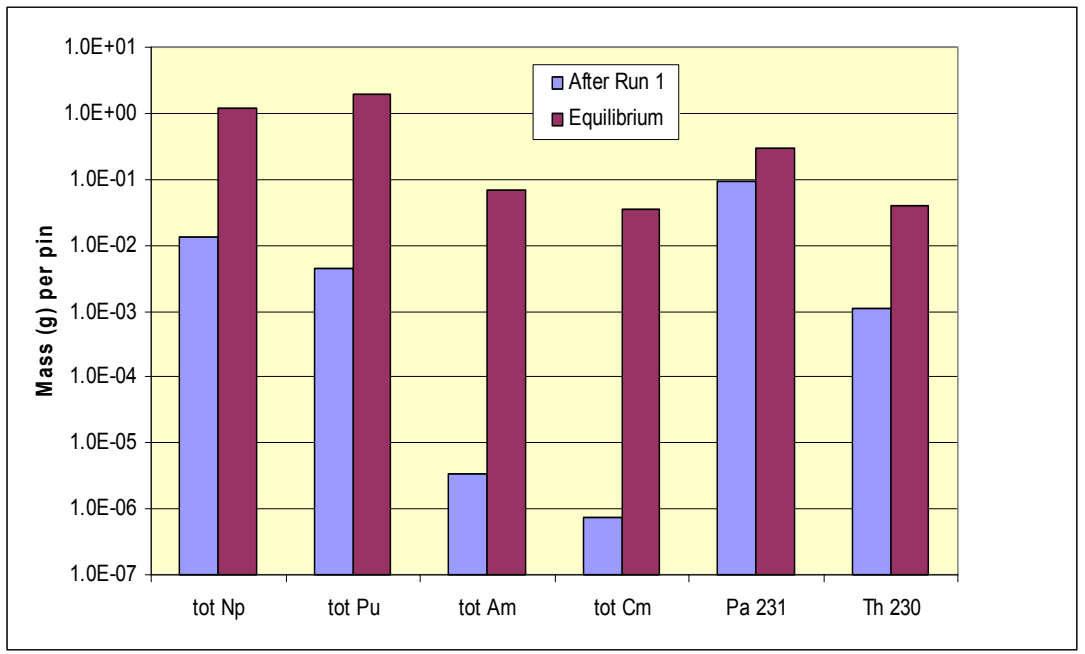

Figure 10. Total mass of the Pu isotopes per fuel pin after the 1st recycle.

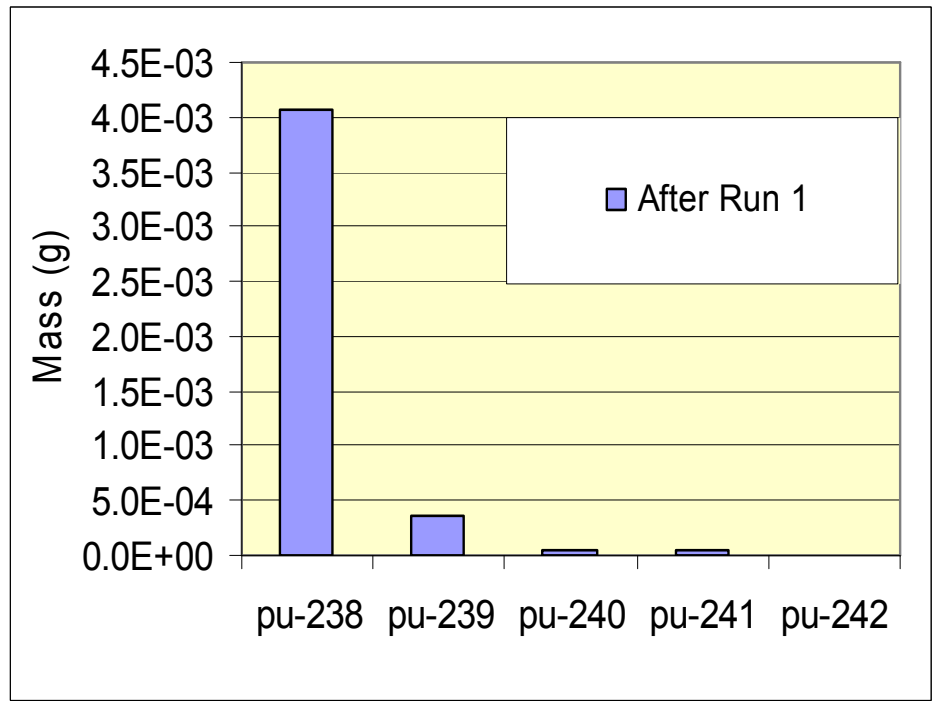

Figure 11. Total mass of the $\mathrm{Pu}$ isotopes per fuel pin at equilibrium.

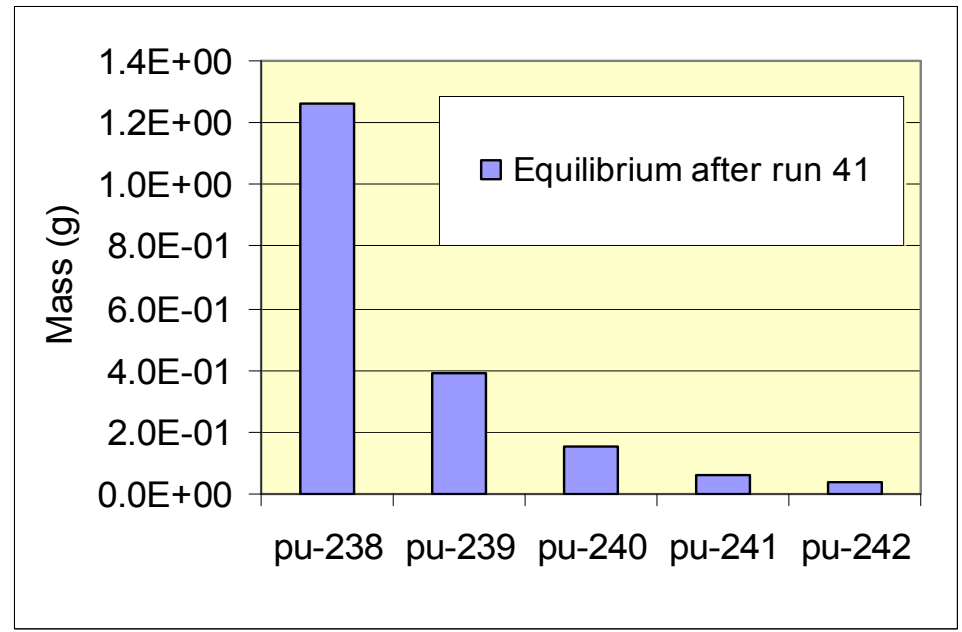


Figure 12. Total mass per fuel pin for the equilibrium cycle of the Am isotopes.

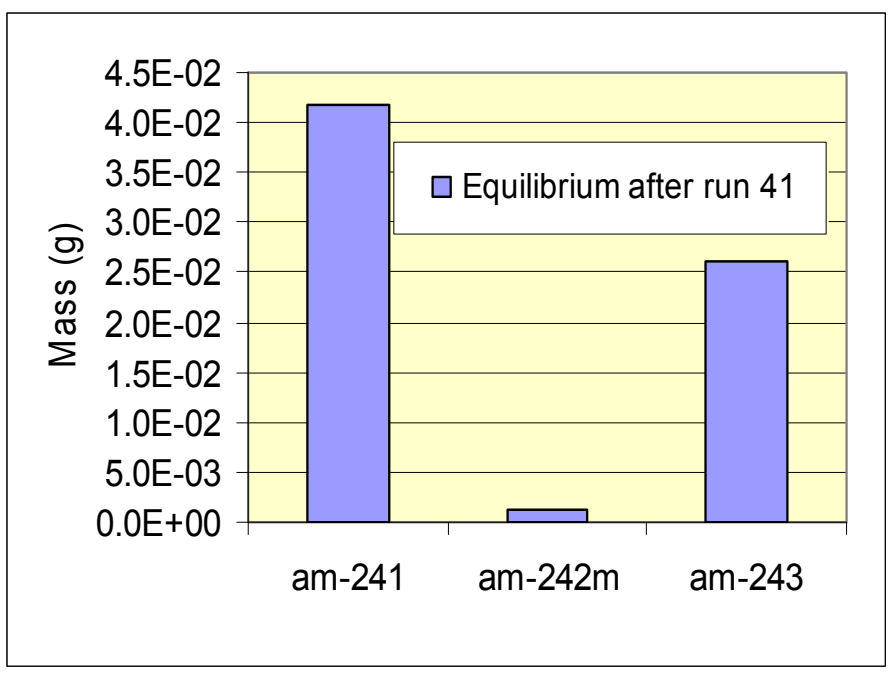

Figure 13. Total mass per fuel pin for the equilibrium cycle of the $\mathrm{Cm}$ isotopes.

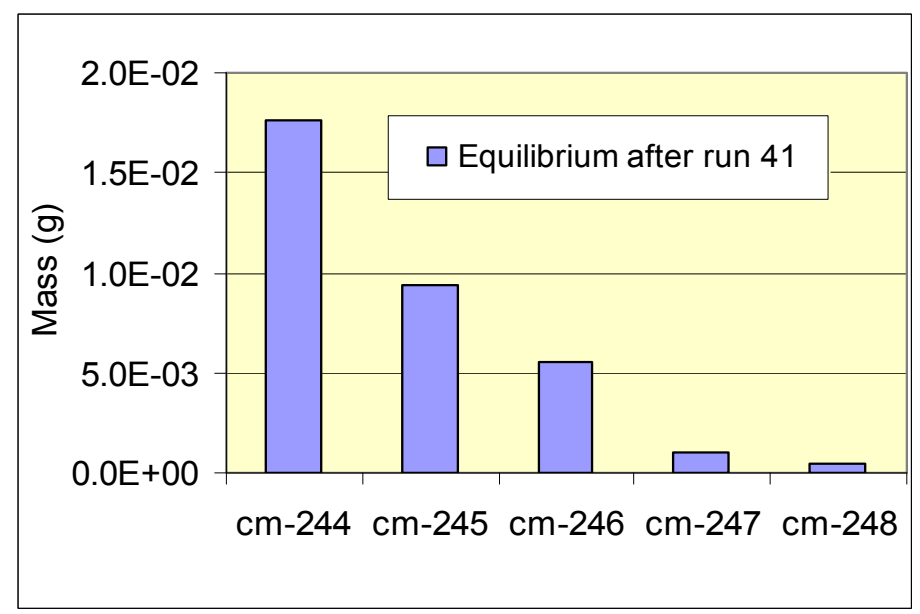

Figure 14. Total mass per fuel pin for the equilibrium cycle of the $U$ isotopes, excluding ${ }^{233} \mathrm{U}$.

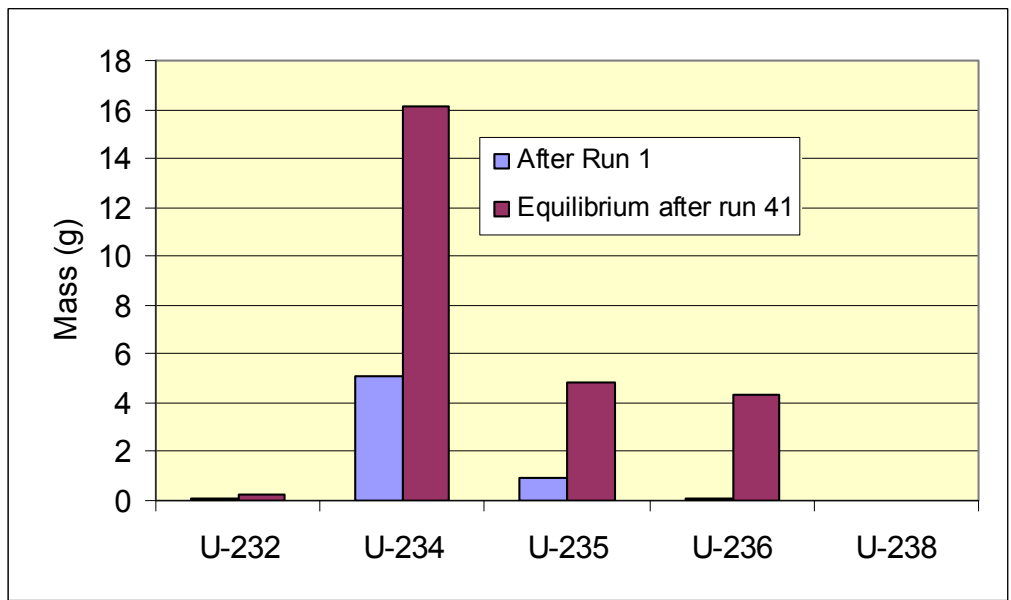


Figure 15 and Figure 16 show how the concentration of ${ }^{232} \mathrm{Th}$ and ${ }^{233} \mathrm{U}$ is redistributed over the fuel residence time in the equilibrium core. By definition, the total core mass of each actinide, except thorium, is the same at the beginning (BOL) and at the end (EOL) of the fuel rod. The axial concentration distribution, though, varies over the fuel residence time because the BOL composition is not the equilibrium composition. The latter depends on the axial variation in the neutron spectrum and power density.

Figure 15. ${ }^{232} \mathrm{Th}$ concentration distribution along the fuel pin at BOL and EOL in the equilibrium core (the vertical axis in the plot is by zone number and not by actual zone length: for this reason the segments are not in the correct proportions to each other).

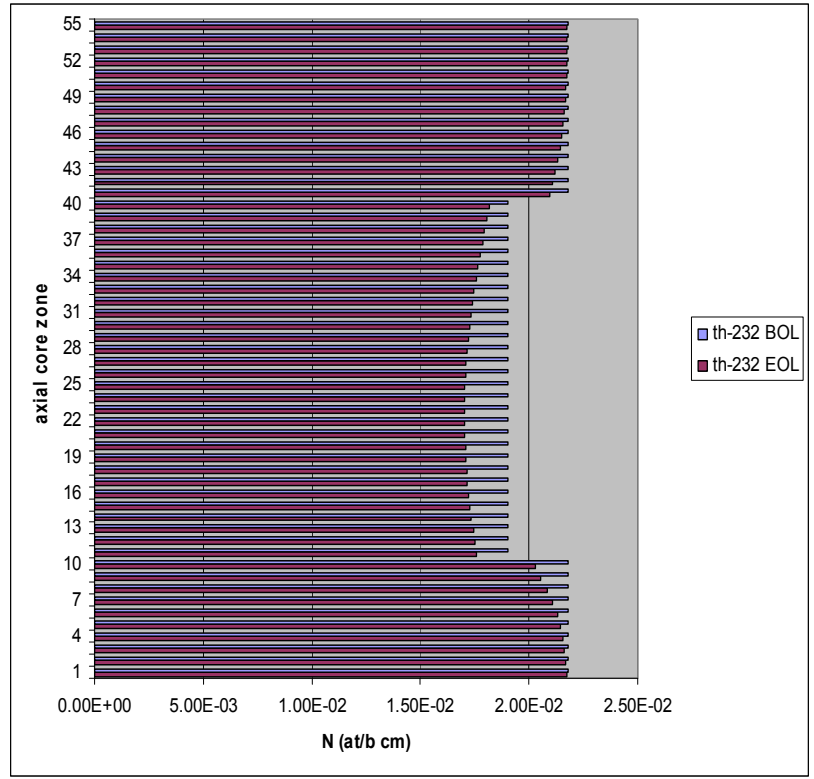

Figure 16. ${ }^{233} \mathrm{U}$ concentration distribution along the fuel pin at BOL and EOL in the equilibrium core (the vertical axis in the plot is by zone number and not by actual zone length: for this reason the segments are not in the correct proportions to each other).

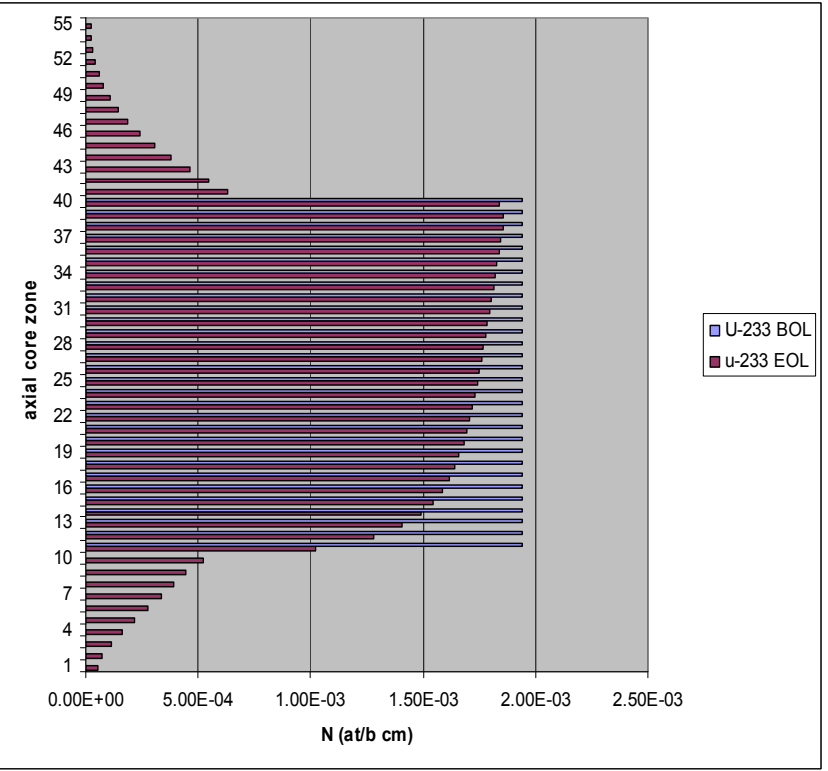


Although a larger fraction of the ${ }^{232} \mathrm{Th}$ is converted to ${ }^{233} \mathrm{U}$ at the lower part than at the upper part of the fissile zone (Figure 15), the ${ }^{233} \mathrm{U}$ EOL concentration is significantly smaller at the lower part than at the upper part of the fissile zone (Figure 16). This is due to the fact that the spectrum is softer at the lower part of the core as a result of which the effective absorption cross section of ${ }^{233} \mathrm{U}$ is larger and also because the power density tends to be skewed towards the bottom of the core (see below).

Figure 17 shows the redistribution of the ${ }^{235} \mathrm{U}$.

Figure 17. ${ }^{235} \mathrm{U}$ concentration distribution along the fuel pin at Beginning of Cycle (BOL) and at End of Cycle (EOL) in the equilibrium core.

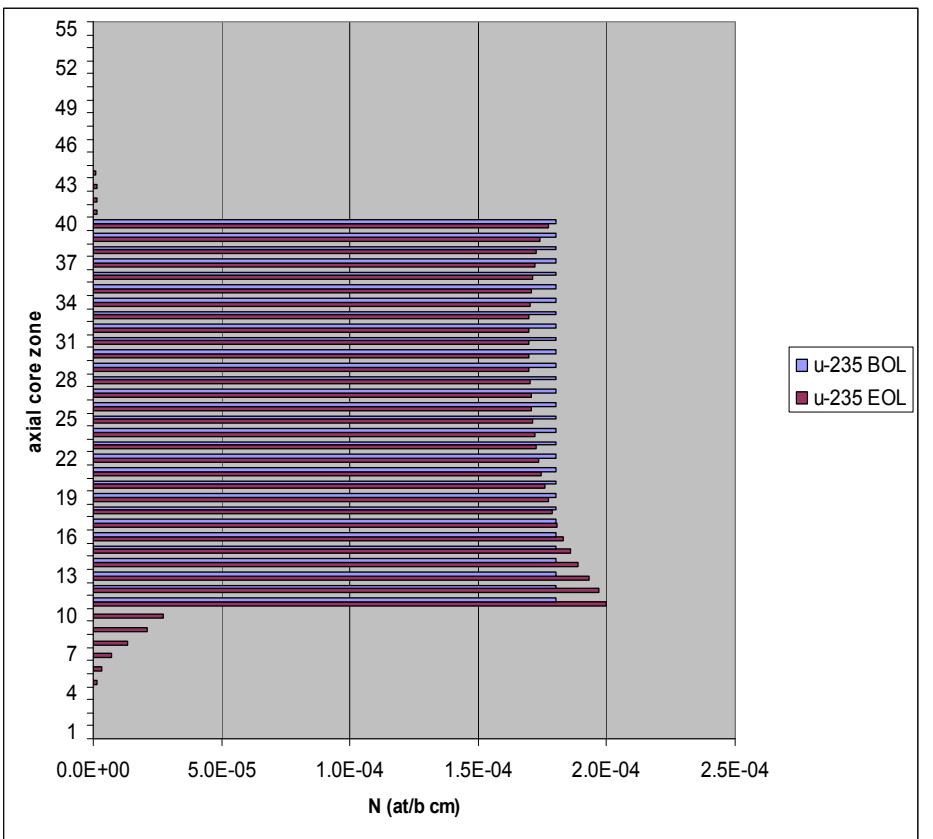

The linear heat generation rate axial distribution at the beginning, middle and end of the fuel life in the equilibrium core is given in Figure 18. These distributions pertain to a radially infinite core made of fuel rods having the BOL, MOL and EOL composition. The axial power distribution in the actual core will be bounded by the BOL and EOL distributions shown in the figures; the MOL axial power distribution is expected to be the closest representation of the axial power distribution in the actual equilibrium core. However, the magnitude of the peak linear heat generation rate in the actual core will be higher by the radial power peaking factor. Assuming the radial peaking factor of $\sim 1.25$ (which is the case for the Hitachi RBWR core designs [1,2]), the peak linear heat generation rate of $280 \mathrm{~W} / \mathrm{cm}$ of Figure 18 corresponds to $\sim 350 \mathrm{~W} / \mathrm{cm}$. This upper bound on the peak linear heat generation rate in the actual (finite) core is comfortably below the maximum acceptable value of $472 \mathrm{~W} / \mathrm{cm}$ used by Hitachi for the RBWR-AC core design [1,2].

With burnup, the axial power shape flattens as the fissile concentration at the lower part of the fissile zone is depleted (Figure 16) and as ${ }^{233} \mathrm{U}$ and, hence, the fission rate, builds up in the blankets. If necessary, it is possible to significantly flatten the BOL axial power distribution by grading the initial fissile fuel concentration loaded onto the fuel rods-loading a smaller concentration in the lower part and a higher in the upper part of the core. 
Figure 18. Linear heat generation rate along the fuel pin at Beginning of Life (BOL), Middle of Life (MOL) and at End of Life (EOL) in the equilibrium core.

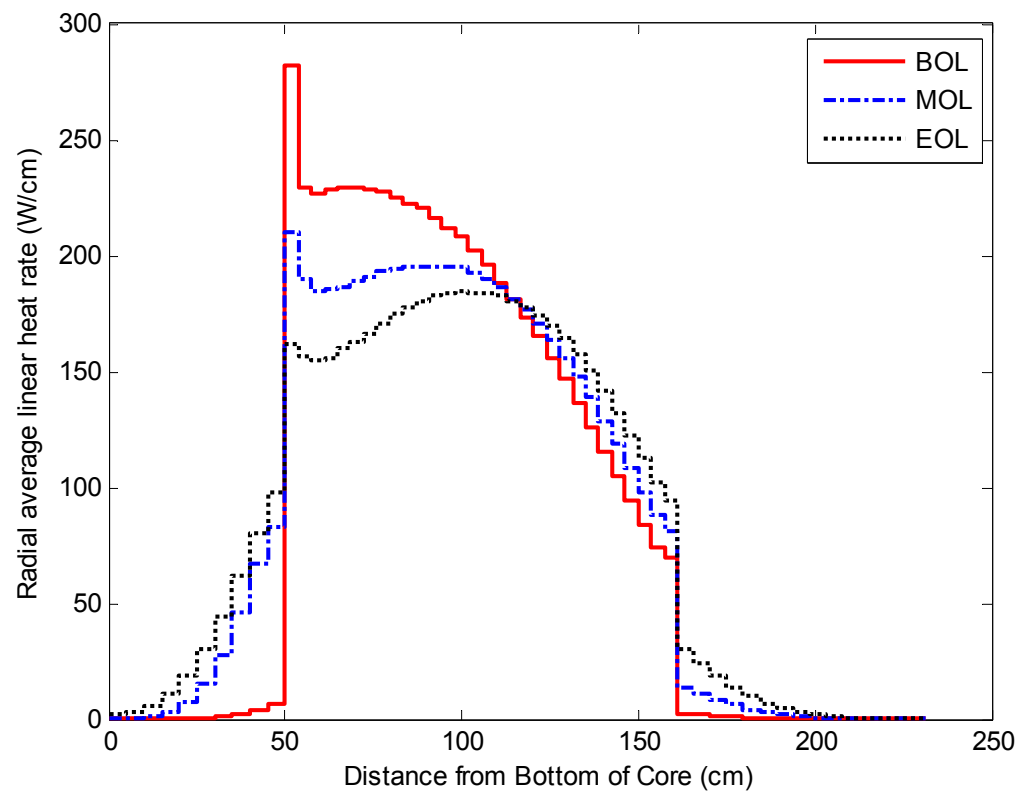

The calculated void reactivity effects at the beginning and end of each of the five batches of the equilibrium core are given in Table 3. It is observed that the void coefficients of reactivity are negative and becoming less so with burnup. They are smaller in absolute value than for the initial core [4] due to the difference in the seed composition. The less negative value of the void coefficient of reactivity at EOL relative to BOL is due, mostly, to the buildup of fissile isotopes in the blankets that increases the effective core height and reduces the voiding contribution to increase in the neutron leakage probability. The core average void reactivity effect will be a weighted average of the 5 batch values and, hence, will be negative. The void reactivity coefficients of the actual core are expected to be somewhat more negative than those given in Table 3 due to the contribution of neutron leakage in the radial direction that is not accounted for in the unit cell model.

Table 3. Unit cell reactivity effect of 5\% coolant flow reduction (denoted by "f95") in the equilibrium core of the reference design.

\begin{tabular}{cccccccc}
\hline $\begin{array}{c}\text { Fraction of } \\
\text { residence time }\end{array}$ & $\begin{array}{c}\text { Nominal } \\
\mathbf{k}_{\text {eff }}\end{array}$ & $\begin{array}{c}\text { Nominal } \\
\mathbf{s t d e v}\end{array}$ & $\begin{array}{c}\mathbf{f 9 5} \\
\mathbf{k}_{\text {eff }}\end{array}$ & $\begin{array}{c}\mathbf{f 9 5} \\
\mathbf{s t d e v}\end{array}$ & $\begin{array}{c}\text { Reactivity } \\
\text { effect (pcm) }\end{array}$ & $\begin{array}{c}\text { stdev } \\
(\mathbf{p c m})\end{array}$ & $\begin{array}{c}\mathbf{3 ~ s t d e v} \\
(\mathbf{p c m})\end{array}$ \\
\hline $0(\mathrm{BOL})$ & 1.14168 & $5.9 \mathrm{E}-05$ & 1.13863 & $5.7 \mathrm{E}-05$ & -234.7 & 8.2 & 24.6 \\
$1 / 5$ & 1.11048 & $5.7 \mathrm{E}-05$ & 1.10832 & $5.6 \mathrm{E}-05$ & -176.0 & 8.0 & 24.0 \\
$2 / 5$ & 1.09335 & $5.7 \mathrm{E}-05$ & 1.09092 & $5.6 \mathrm{E}-05$ & -203.6 & 8.0 & 24.0 \\
$3 / 5$ & 1.07737 & $5.7 \mathrm{E}-05$ & 1.07544 & $5.7 \mathrm{E}-05$ & -166.8 & 8.1 & 24.2 \\
$4 / 5$ & 1.06363 & $5.6 \mathrm{E}-05$ & 1.06234 & $5.5 \mathrm{E}-05$ & -114.9 & 7.8 & 23.5 \\
$1.0(\mathrm{EOL})$ & 1.05204 & $5.7 \mathrm{E}-05$ & 1.05126 & $5.6 \mathrm{E}-05$ & -70.6 & 8.0 & 24.0 \\
\hline
\end{tabular}

Table 4 gives the $k_{\text {eff }}$ value in the fully voided and cold zero power (CZP) conditions at BOL (Burnup Step 0) and at the end of each of the five batches of the equilibrium core, all without control rods insertion. The coolant density in the core $\left(0\right.$ and $1 \mathrm{~g} / \mathrm{cm}^{3}$, respectively) is extended to the lower and upper reflectors. It is observed that in the voided conditions the core has lower reactivity than in 
the nominal condition, but is supercritical. However, the excess reactivity could be readily compensated by the control and/or safety rods. On the other hand, at CZP conditions the excess reactivity is very high and may be impractical to compensate with the control and safety rods. That is, it appears very challenging, if not impractical, to provide adequate shutdown safety margin in this point design.

Table 4. Unit cell $\mathrm{k}_{\mathrm{eff}}$ and standard deviation (stdev) in fully voided and Cold Zero Power (CZP) conditions in equilibrium core of reference design.

\begin{tabular}{cccccccc}
\hline $\begin{array}{c}\text { Fraction of } \\
\text { residence time }\end{array}$ & $\begin{array}{c}\text { BU } \\
\text { step }\end{array}$ & $\begin{array}{c}\text { Nominal } \\
\mathbf{k}_{\text {eff }}\end{array}$ & $\begin{array}{c}\text { Nominal } \\
\text { stdev }\end{array}$ & $\begin{array}{c}\mathbf{C Z P} \\
\mathbf{k}_{\text {eff }}\end{array}$ & $\begin{array}{c}\mathbf{C Z P} \\
\mathbf{s t d e v}\end{array}$ & $\begin{array}{c}\text { Full void } \\
\mathbf{k}_{\text {eff }}\end{array}$ & $\begin{array}{c}\text { Full void } \\
\text { stdev }\end{array}$ \\
\hline $0(\mathrm{BOL})$ & 0 & 1.141693 & $6.1 \mathrm{E}-05$ & 1.43 & $6.8 \mathrm{E}-05$ & 1.08201 & $4.9 \mathrm{E}-05$ \\
$1 / 5$ & 1 & 1.109711 & $5.5 \mathrm{E}-05$ & 1.34 & $6.4 \mathrm{E}-05$ & 1.06288 & $4.5 \mathrm{E}-05$ \\
$2 / 5$ & 2 & 1.09157 & $6.1 \mathrm{E}-05$ & 1.29 & $6.5 \mathrm{E}-05$ & 1.05343 & $5.0 \mathrm{E}-05$ \\
$3 / 5$ & 3 & 1.076256 & $5.7 \mathrm{E}-05$ & 1.26 & $5.9 \mathrm{E}-05$ & 1.04530 & $4.9 \mathrm{E}-05$ \\
$4 / 5$ & 4 & 1.063234 & $5.7 \mathrm{E}-05$ & 1.23 & $6.1 \mathrm{E}-05$ & 1.03810 & $5.2 \mathrm{E}-05$ \\
$1.0(\mathrm{EOL})$ & 5 & 1.051665 & $5.7 \mathrm{E}-05$ & 1.21 & $6.7 \mathrm{E}-05$ & 1.03199 & $5.1 \mathrm{E}-05$ \\
\hline
\end{tabular}

The core average $\mathrm{k}_{\text {eff }}$ values will be a weighted average of the 5 batch values. Table 5 gives a rough estimate of the $\mathrm{k}_{\mathrm{eff}}$ value of the reference core at beginning (BOEC), middle (MOEC) and end (EOEC) of the equilibrium cycle obtained by applying the linear reactivity model to the averaging of the 5-batch data of Table 4. As the linear reactivity model gives an equal weight to the 5 batches and as in the real core the 4th and 5th batches are located near the core radial periphery where the power density is lower and the importance function is lower, it is expected that the linear reactivity averaging underestimates the expected real core value. As the nominal EOEC $\mathrm{k}_{\mathrm{eff}}$ is larger than the design objective of 1.025 this core should have been calculated to higher discharge burnup or, else, should be operated with a small breeding gain - a small fraction of the uranium (and, possibly, trans-thorium elements) should be removed from the reprocessed fuel so as to reduce the BOEC (and, therefore, also EOEC) $k_{\text {eff. }}$ Table 5 also gives $k_{\text {eff }}$ values that are adjusted to EOEC $k_{\text {eff }}$ of 1.025 by subtracting $(1.078-1.025=) 0.053$ from all the $k_{\text {eff }}$ values. Although not exact, the adjusted $k_{\text {eff }}$ values well represent the values expected from a well converged and consistent design.

Table 5. Average $\mathrm{k}_{\mathrm{eff}}$ at nominal and CZP condition of the reference core.

\begin{tabular}{lcccc}
\hline $\begin{array}{l}\text { Time in } \\
\text { Cycle }\end{array}$ & $\begin{array}{c}\text { Nominal } \\
\mathbf{k}_{\text {eff }}\end{array}$ & $\begin{array}{c}\mathbf{C Z P} \\
\mathbf{k}_{\text {eff }}\end{array}$ & $\begin{array}{c}\text { Adjusted } \\
\text { Nominal } \mathbf{k}_{\text {eff }}\end{array}$ & $\begin{array}{c}\text { Adjusted CZP } \\
\mathbf{k}_{\text {eff }}\end{array}$ \\
\hline BOEC & 1.096 & 1.306 & 1.043 & 1.253 \\
MOEC & 1.087 & 1.284 & 1.034 & 1.231 \\
EOEC & 1.078 & 1.264 & 1.025 & 1.211 \\
\hline
\end{tabular}

It is concluded that it is possible to obtain a fuel-self-sustaining boiling-water-cooled core based on thorium-dioxide-fuel. The core features stationary fuel and relatively uniform fuel assemblies. It uses the tight lattice, radial dimensions and coolant outlet void fraction of the Hitachi RBWR-AC core $[1,2]$ and could fit within an ABWR pressure vessel. The core analyzed is made of a $\sim \mathrm{m}$ long zone initially loaded with a mixture of ${ }^{233} \mathrm{UO}_{2}$ and $\mathrm{ThO}_{2}$ with a $\mathrm{ThO}_{2}$ blanket on top and bottom of it. The peak 
linear heat generation rate is significantly smaller than that of the RBWR-AC core that is designed to have a power level of $4000 \mathrm{MW}_{\text {th }}$. All the reactivity coefficients, including the void reactivity coefficient, are negative throughout the fuel life. However, a safety issue that has not been resolved yet is the insufficient shutdown reactivity margin at cold zero power conditions. Design modifications that will provide adequate shutdown margin are required. One possible design recently identified is described in the following section.

\section{Alternative Core Design}

An approach explored for reducing the magnitude of the coolant void reactivity effect and, thus, reducing the CZP $\mathrm{k}_{\text {eff }}$, is to add to the seed a small amount of plutonium from LWR used nuclear fuel, thus making the resulting core a LWR plutonium transmuter while generating most of the energy from a self-sustaining thorium-based fuel cycle. A parametric search was made to identify the maximum amount of $\mathrm{Pu}$ that can be added before turning the void reactivity effect at the EOL from negative to positive. The amount of $\mathrm{Pu}$ addition found optimal was 1.2 weight percent. The core performance is estimated from a single pin-cell burnup analysis assuming a 5-batch fuel-management scheme as done for the reference case analysis described above. The pin power assumed for this analysis is $40 \mathrm{KW}_{\text {th }}$ - twice the value assumed for the reference unit cell analysis (Section 4). Figure 19 shows the $\mathrm{k}_{\mathrm{eff}}$ evolution of a unit cell in the equilibrium cycle. The EOEC 5-batch core average $\mathrm{k}_{\text {eff }}$ design objective is 1.025 , as in Section 4. The burnup achieved in one cycle is 14.98 GWD per metric ton of all the heavy-metal (HM), including that in the blankets and the cycle length is 1.22 full power years. The average discharge burnup is 74.9 GWD/MTiHM after 5 cycles in the core, for a total fuel life of 6.12 years. The core is featuring a Fissile Inventory Ratio (FIR) of 1.01 accounting for ${ }^{233} \mathrm{U},{ }^{235} \mathrm{U}$, ${ }^{239} \mathrm{Pu}$ and ${ }^{241} \mathrm{Pu}$ at the end of a 3-years cooling/recycling time. The variation of the axial dependent concentration of selected isotopes from BOL to EOL in the alternative design is shown in Figures 20 through 22 .

Figure 19. $\mathrm{k}_{\mathrm{eff}}$ evolution of the unit cell of the equilibrium cycle of the alternative design.

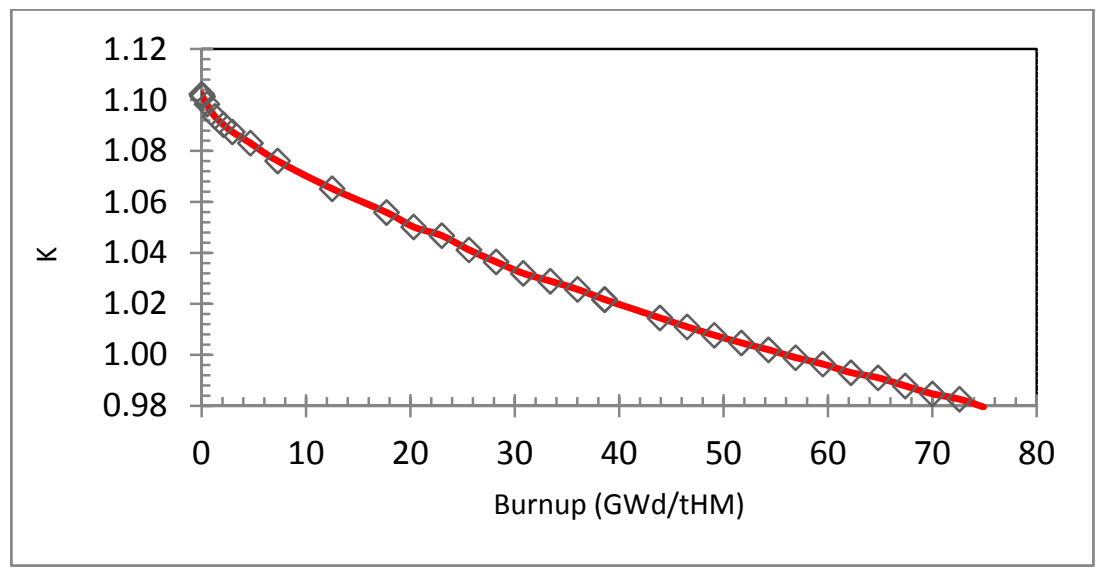


Figure 20. ${ }^{232}$ Th concentration distribution along the fuel pin at BOL and EOL in the equilibrium core of the alternative design.

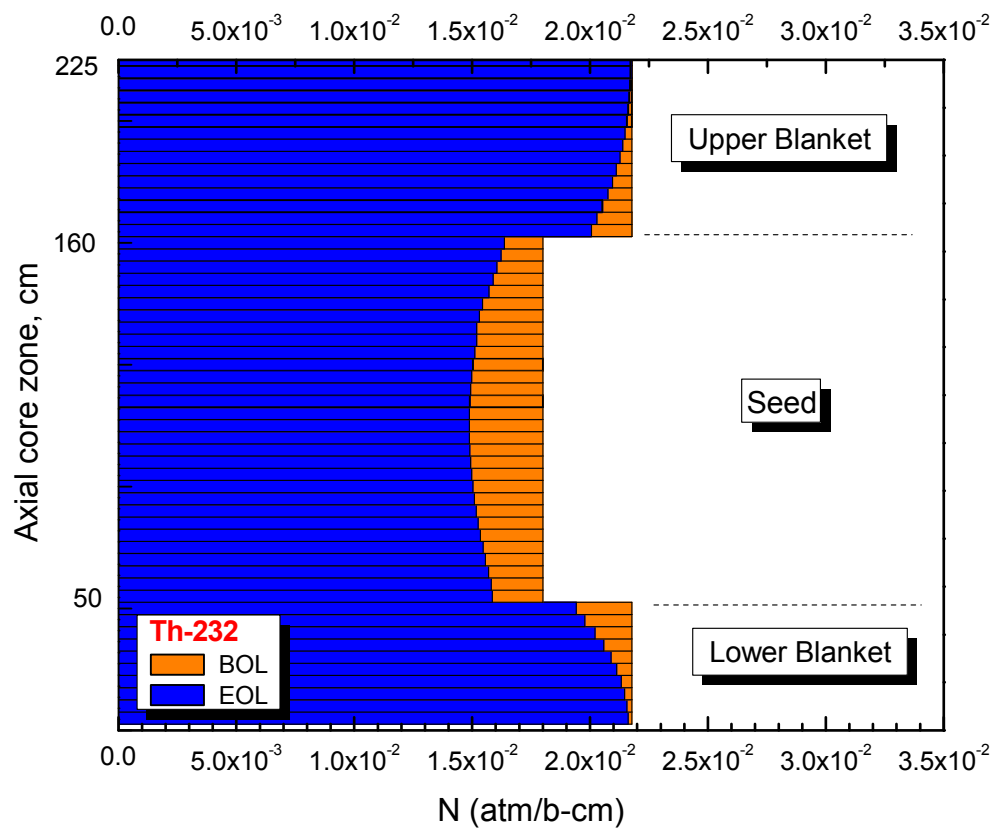

Figure 21. ${ }^{233} \mathrm{U}$ concentration distribution along the fuel pin at BOL and EOL in the equilibrium core of the alternative design.

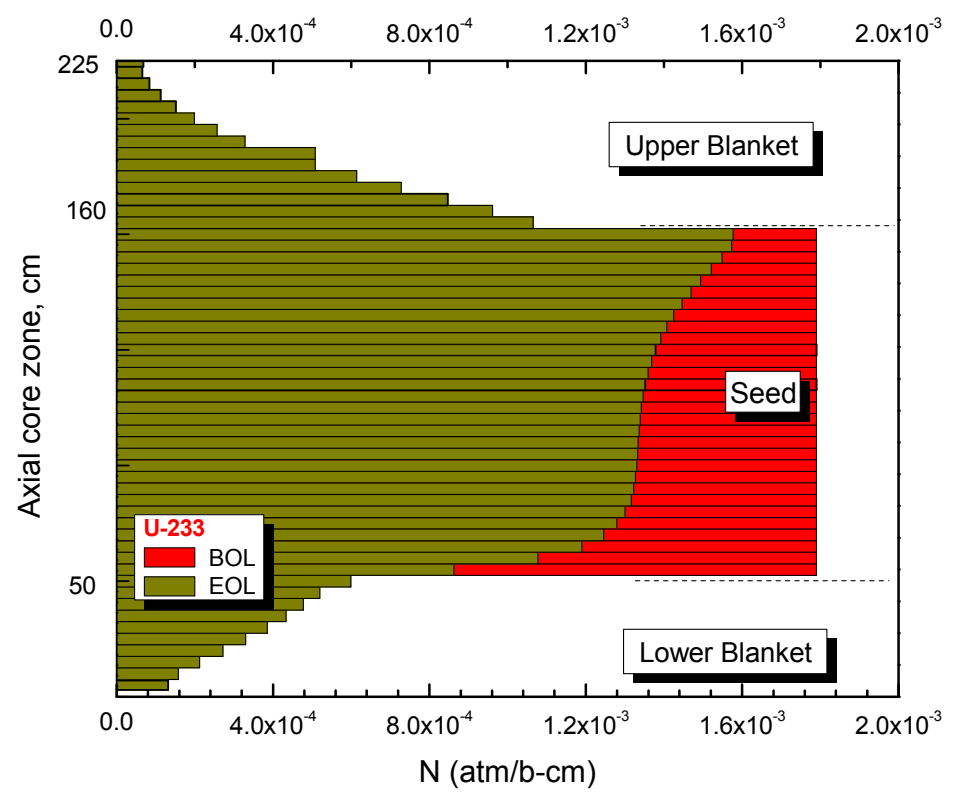


Figure 22. ${ }^{239} \mathrm{Pu}$ concentration distribution along the fuel pin at $\mathrm{BOL}$ and $\mathrm{EOL}$ in the equilibrium core of the alternative design.

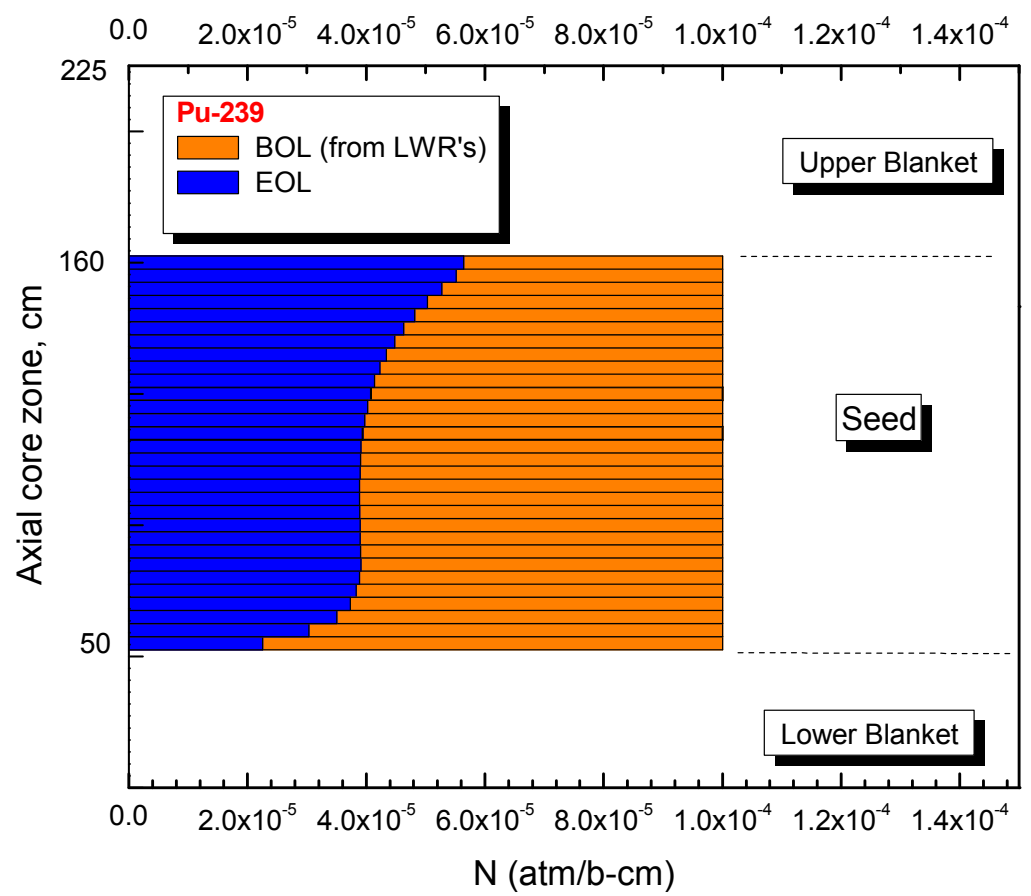

The BOL isotopic distribution of selected elements is given in Figures 23 to 25 . All these compositions pertain to the equilibrium cycle. The overall trends are similar to those displayed in Section 4 for the reference pin cell.

Figure 23. Amount of uranium isotopes in a fuel pin of the alternative core design at equilibrium.

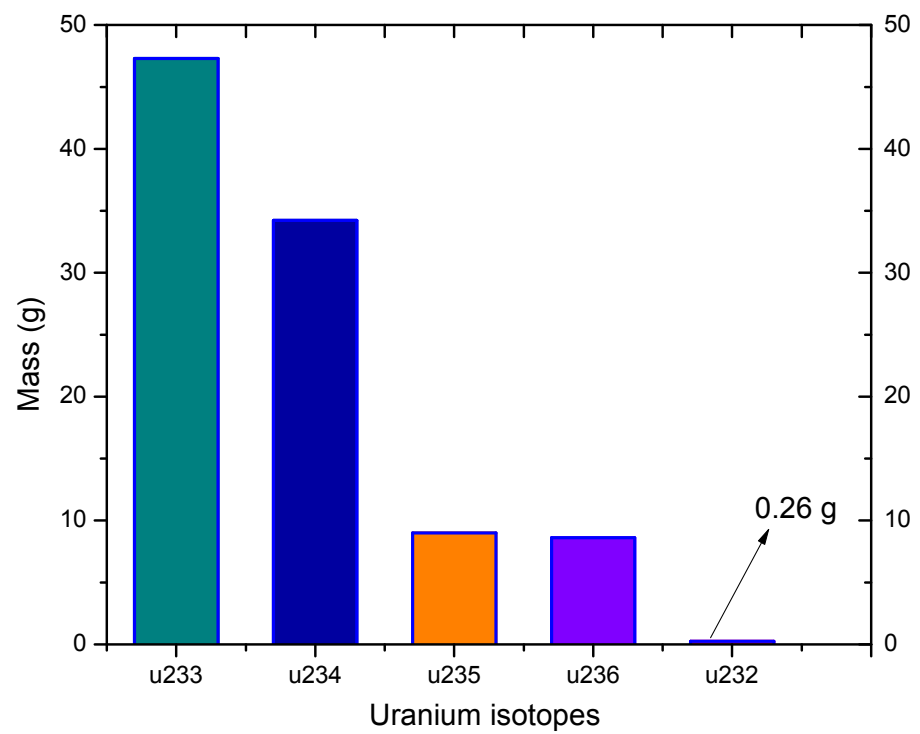


Figure 24. Amount of plutonium isotopes in a fuel pin at the beginning and end of life in the alternative core design at equilibrium.

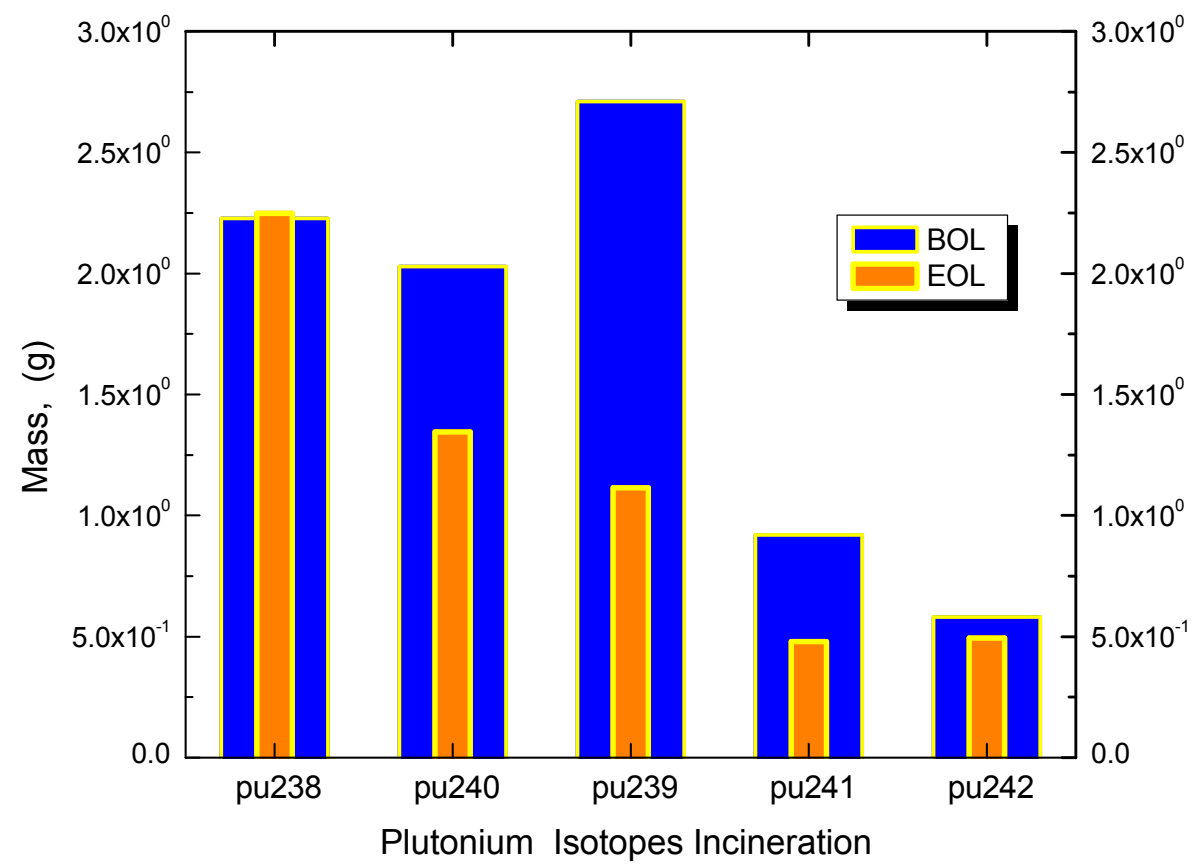

Figure 25. Amount of $\mathrm{Np}, \mathrm{Am}$ and $\mathrm{Cm}$ isotopes in a fuel pin of the alternative core design at equilibrium.

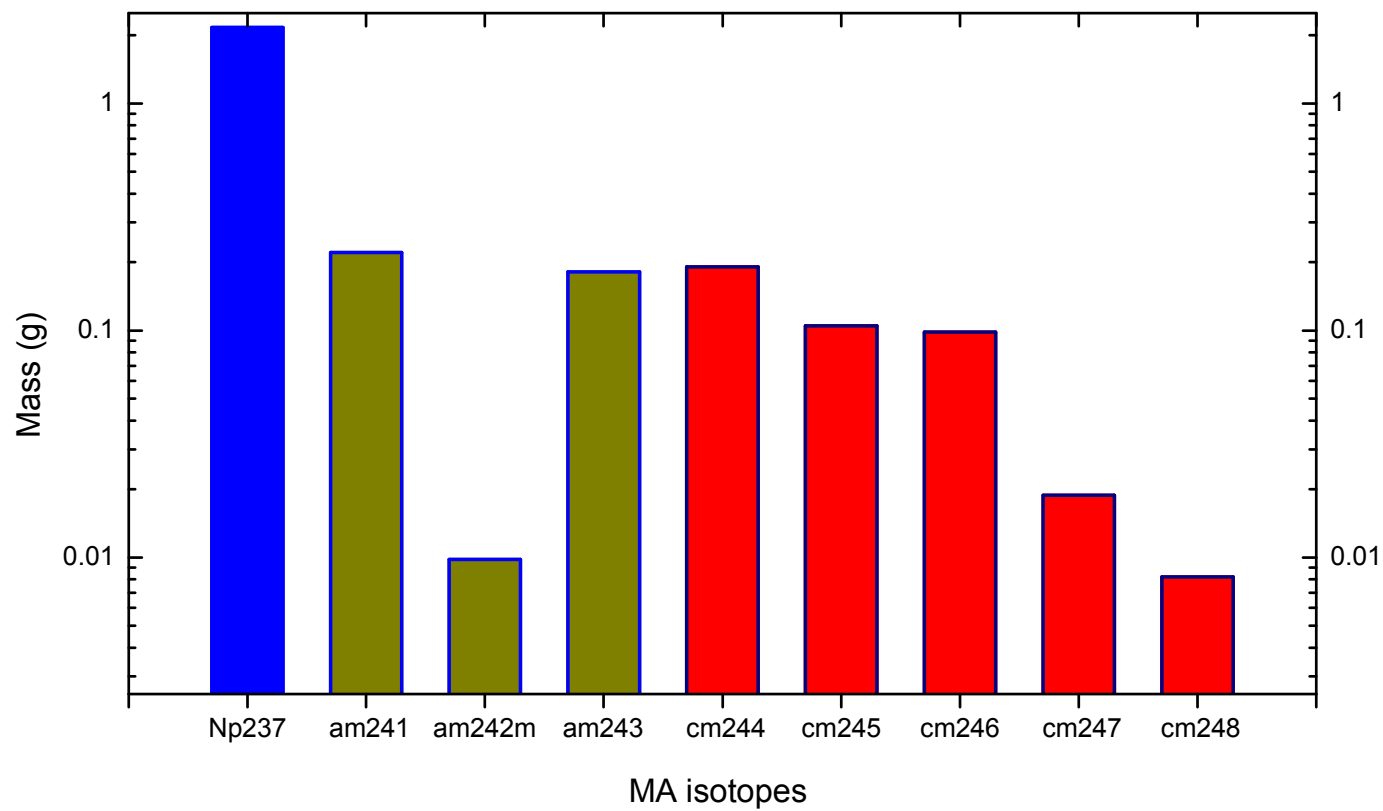

The amount of ${ }^{233} \mathrm{U}$ is slightly smaller than in the reference core (Figure 5) but the amount of plutonium is higher (Figure 24 versus Figure 11). However, the amount of plutonium in the alternative core is only $0.5 \%$ of the HM- even less than in typical LWR Used Nuclear Fuel (UNF). Nearly $60 \%$ 
of the loaded ${ }^{239} \mathrm{Pu}$ is transmuted over the equilibrium cycle so that the fissile plutonium isotopes constitute only $27.6 \%$ of the total plutonium discharged-less than half the fraction in LWR UNF. The discharged ${ }^{238} \mathrm{Pu}$ concentration is very high-about $40 \%$ versus approximately $1 \%$ in LWR UNF. Hence, the plutonium in this RBWR discharged fuel will probably not be of proliferation concerns. The fissile uranium concentration is of significantly more proliferation concern and it may be desirable to denature the uranium by adding some depleted uranium to the thorium. This option will be explored in the future.

The axial power profile of the unit cell having the composition of the equilibrium core are shown for BOL, MOL and EOL in Figure 26. The total pin power assumed is $40 \mathrm{~kW}_{\text {th }}$-twice that assumed for the reference pin design. The peak pin linear heat generation rate is close to $450 \mathrm{~W} / \mathrm{cm}$. Assuming, as in Section 4, a core radial power peaking factor of 1.25, the peak core linear heat generation rate is estimated to be $562 \mathrm{~W} / \mathrm{cm}$ - significantly larger than the Hitachi design constraint of $472 \mathrm{~W} / \mathrm{cm}$. Nevertheless, a core based on the alternative fuel design could possibly safely operate at $\sim 75 \%$ of the assumed power level; that is, at $\sim 6000 \mathrm{MW}_{\text {th }}$ or $\sim 150 \%$ of the nominal ABWR power level. This is because the axial power peaking factor of the alternative design is significantly smaller than that of the reference unit cell (Figure 18); if normalized to the same total pin power of $20 \mathrm{~kW}_{\text {th }}$, the peak linear heat generation rate is $225 \mathrm{~W} / \mathrm{cm}$ versus $280 \mathrm{~W} / \mathrm{cm}$ of Figure 18.

Figure 26. Axial variation of the linear heat generation rate along the fuel pin at BOL, MOL and EOL of the equilibrium cycle of the alternative core design. Total pin power is $40 \mathrm{~kW}_{\mathrm{th}}$.

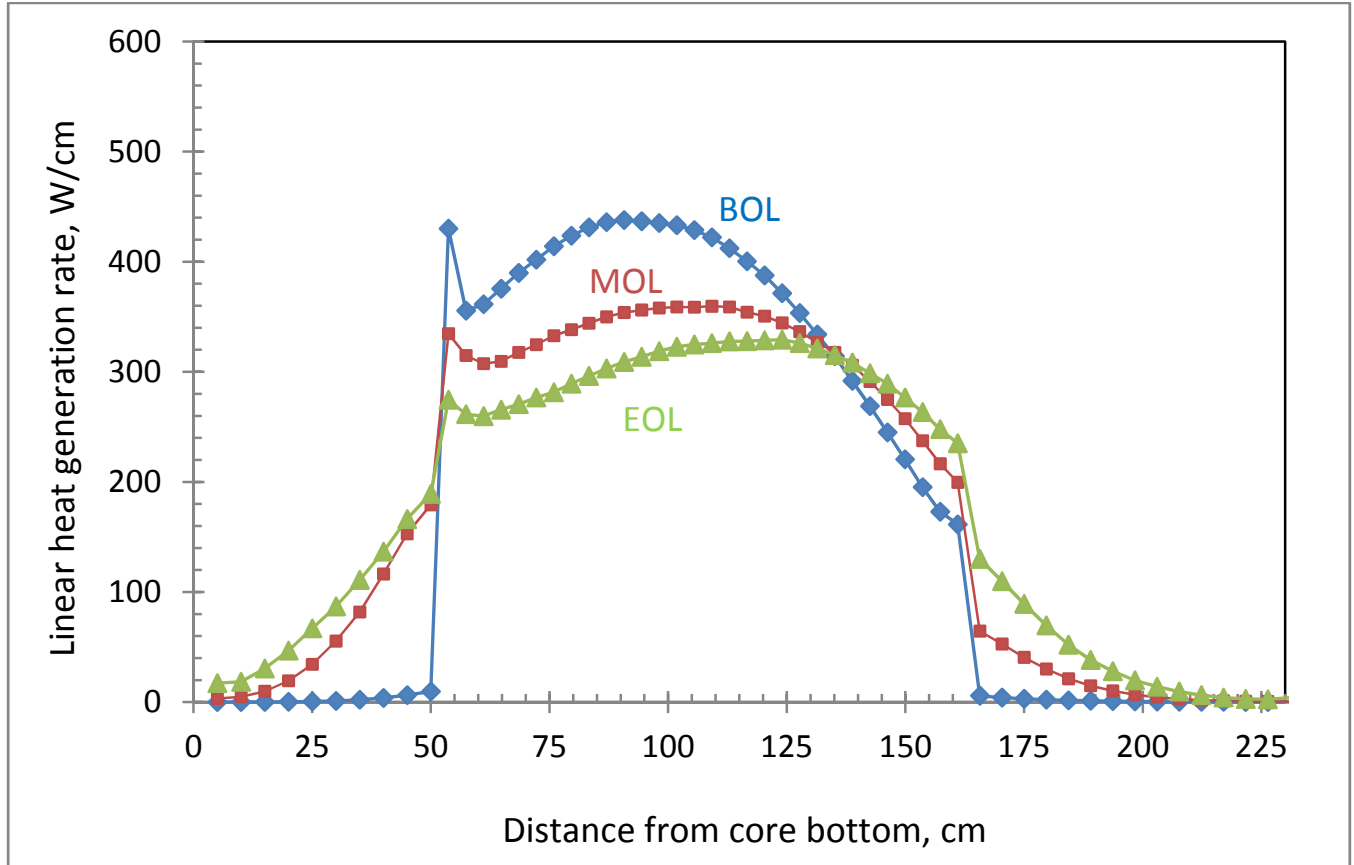

Table 6 gives the $\mathrm{k}_{\text {eff }}$ value in the nominal, voided, and cold zero power (CZP) conditions at BOL (Burnup Step 0) and at the end of each of the five batches of the equilibrium core of the alternative design, all without control rods insertion. The voiding considered is an arbitrary $20 \%$ reduction from the nominal water density in each of the axial zones from the bottom of the seed and upward. 
Table 6. Unit cell $\mathrm{k}_{\mathrm{eff}}$ in nominal, $20 \%$ voided and CZP conditions in the equilibrium core of the alternative design.

\begin{tabular}{ccccc}
\hline $\begin{array}{c}\text { Fraction of } \\
\text { residence time }\end{array}$ & BU step & $\begin{array}{c}\text { Nominal } \\
\mathbf{k}_{\text {eff }}\end{array}$ & $\begin{array}{c}\mathbf{2 0 \%} \text { voided } \\
\mathbf{k}_{\text {eff }}\end{array}$ & $\begin{array}{c}\text { CZP } \\
\mathbf{K}_{\text {eff }}\end{array}$ \\
\hline $0(\mathrm{BOL})$ & 0 & 1.10 & 1.09 & 1.20 \\
$1 / 5$ & 1 & 1.06 & 1.05 & 1.12 \\
$2 / 5$ & 2 & 1.03 & 1.03 & 1.06 \\
$3 / 5$ & 3 & 1.01 & 1.01 & 1.03 \\
$4 / 5$ & 4 & 0.99 & 0.99 & 1.01 \\
$1.0(\mathrm{EOL})$ & 5 & 0.97 & 0.98 & 0.99 \\
\hline
\end{tabular}

Table 7 gives an estimate of the core average CZP $\mathrm{k}_{\mathrm{eff}}$ and void reactivity effect at BOEC, MOEC and EOEC values obtained using the linear reactivity approximation. The actual value of the void coefficient of reactivity is expected to be somewhat more negative than that given in the table because the effect of radial neutron leakage is not accounted for. This radial leakage effect is likely to make the EOEC void reactivity effect—slightly positive in Table 7, negative. If not, slight design modifications could do so.

Table 7. Core average reactivity effect of $20 \%$ voiding and CZP $\mathrm{k}_{\mathrm{eff}}$ of the alternative core design equilibrium core.

\begin{tabular}{lcc}
\hline Time in Cycle & $\begin{array}{c}\mathbf{k}_{\text {void }}-\mathbf{k}_{\text {nominal }} \\
(\mathbf{p c m})\end{array}$ & $\begin{array}{c}\mathbf{C Z P} \\
\mathbf{k}_{\text {eff }}\end{array}$ \\
\hline BOEC & -166.2 & 1.079 \\
MOEC & -66.9 & 1.056 \\
EOEC & +4.6 & 1.039 \\
\hline
\end{tabular}

Figure 27 compares the core CZP $\mathrm{k}_{\text {eff }}$ over the equilibrium cycle for the reference and alternative designs. It is seen that the alternative design CZP $\mathrm{k}_{\mathrm{eff}}$ is significantly smaller and is likely manageable.

Figure 27. Core average CZP $k_{\text {eff }}$ values at the beginning, middle and end of the equilibrium cycle of the reference and alternative cores.

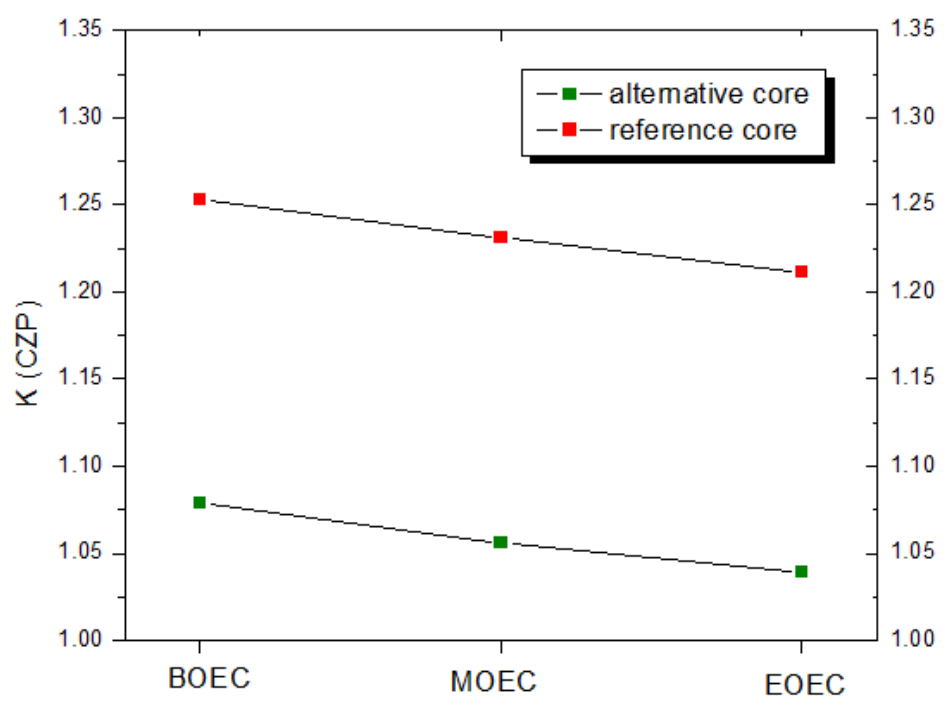


However, a preliminary analysis performed for the equilibrium core composition indicates that the axial variation of the reactivity effect of local voiding of the coolant has a wavy behavior with positive in addition to negative components, as illustrated in Figure 28 . The axially integrated change in $\mathrm{k}_{\infty}$ is consistent with the results reported in Table 7. The axial zone dependent void reactivity effect was calculated using a methodology similar to that described in detail in reference [14]. Briefly, the method calculates the contribution of a given axial zone to the $\mathrm{k}_{\infty}$ of the unit cell for the reference under perturbed conditions, and takes the difference between the perturbed and reference values to represent the reactivity effect of the perturbation.

Figure 28. Axial distribution of the effect of voiding $20 \%$ of the coolant in the seed, upper blanket and upper reflector zones on the zone contribution to the unit cell $\mathrm{k}_{\infty}$. Alternative core at equilibrium.

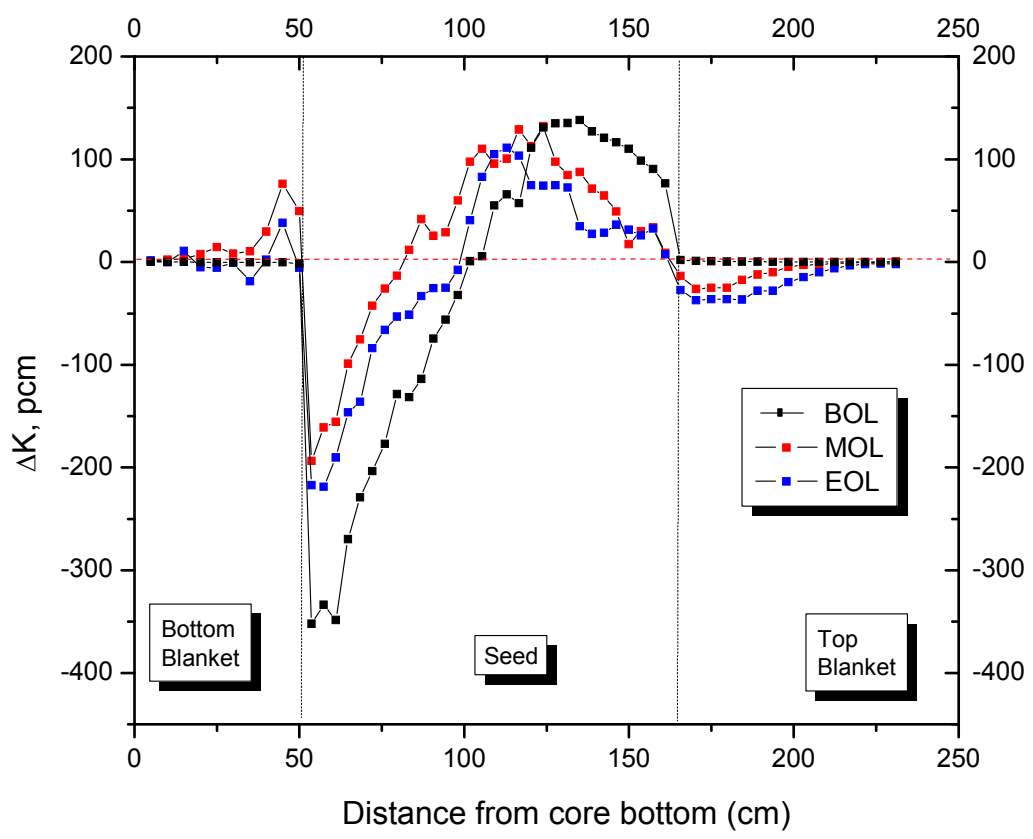

A wavy trend quite similar to that displayed in Figure 28 was more recently obtained using a couple of different methodologies - the, so called, PERT and KPERT options provided by the Monte-Carlo code MCNP6 for the calculation of the effect of perturbation on the system multiplication factor [15]. The results provided by these two perturbation effect calculation options were found [15] consistent with the value inferred from $k_{\text {eff }}$ (perturbed)- $k_{\text {eff }}$ (reference) in which the perturbation consists of $10 \%$ reduction of the reference water density in a single axial zone and each of the $\mathrm{k}_{\text {eff }}$ values was calculated with MCNP to have a standard deviation that is significantly smaller than the $\mathrm{k}_{\text {eff }}$ difference value.

\section{Discussion}

The model used in the early part of this study [4] for predicting the axial water density distribution is not accurate; it tends to over-predict the void fraction in the upper part of the core. Moreover, due to computer time limitation the axial water density distribution was not updated each burnup step but was updated each recycling. A significantly improved computational model presently in use confirms the overall trends presented and conclusions reported in the present work. 
The average discharge burnup of approximately $75 \mathrm{GWd} / \mathrm{tHM}$ reported for the alternative core pertains to the total HM mass in the fuel, including the blanket fuel that makes more than half $(\sim 110 / 230)$ of the HM volume. The peak seed burnup is estimated to be $\sim 155 \mathrm{GWd} / \mathrm{tHM}$. No thorium-oxide based fuel has been irradiated to such high burnups and the fuel rod cladding may not be able to maintain its integrity especially under exposure to a hard neutron spectrum. Therefore it may be necessary to reduce the cycle length and the discharge burnup. This will actually reduce the burnup reactivity swing and the change, over the cycle, in the void reactivity effect. Fuel performance analysis will be undertaken to estimate the discharge burnup limit for the RBWR core. If the discharge burnup will have to be reduced, the system will have a net breeding gain; some of the uranium (and, if desirable, other trans-thorium elements) will have to be removed from the recycled fuel. Alternatively, the water mass flow rate could be increased so as to increase the average water density in the core and thereby to reduce the conversion ratio.

The wavy behavior of the axial distribution of the void reactivity effect displayed in Figure 28 is of concern. Even though the overall reactivity effect due to coolant mass flow rate reduction or to total power increase is negative, the wavy behavior of the axial dependent reactivity effect of coolant voiding may induce unstable axial power oscillations. A more thorough analysis of the axial variation of the coolant density change due to either change in the coolant mass flow rate or change of core power on the local reactivity effect has been initiated. This study will also search for a thorough understanding of the physics phenomena responsible for the uncommon axial behavior of the voiding reactivity effect reported above. A thorough investigation of the effect of the strong axial variation in the void reactivity on the stability of the thorium-based RBWR core is being planned. Design remedies will be searched for if needed. One approach that will be considered is to reduce the core exit void fraction; there is a sufficient margin for breeding in the thorium-based RBWR to accommodate such a design change.

\section{Conclusions}

The preliminary analysis performed so far indicates that it is feasible to design a thorium-based fuel-self-sustaining (breeding) reduced moderation boiling water reactor core that features stationary fuel and radially uniform fuel assembly composition and, hence, is free of power mismatch. The seed-and-blanket arrangement of the proposed design is in the axial direction and is uniformly applied to each of the fuel rods - similar to, though simpler than, the Hitachi RBWR core designs [1,2]. It uses the tight lattice, radial dimensions and coolant outlet void fraction of the Hitachi RBWR-AC core $[1,2]$ and could fit within an ABWR pressure vessel.

The peak linear heat generation rate is estimated to be significantly lower than that of the RBWR-AC core when both cores are designed to have the ABWR power level of close to $4000 \mathrm{MW}_{\text {th }}$; it may be possible to safely operate the proposed thorium-based RBWR core at a significantly higher power, without increasing the ABWR core diameter. All the reactivity coefficients, including the void reactivity coefficient, are negative throughout the fuel life. In fact, the reference design features too negative void reactivity effect making it impractical to achieve an acceptable shutdown reactivity margin at cold zero power condition. The addition of a small amount of plutonium from LWR used nuclear fuel was found effective in reducing the magnitude of the void reactivity coefficient, thus 
providing for an adequate shutdown margin at cold zero power conditions; it also flattens the axial power distribution. This design option offers an efficient incineration of the LWR generated plutonium in addition to effective utilization of thorium. The fissile plutonium fraction in the fuel discharged from this RBWR core is very low and does not pose extra proliferation concerns.

However, even though the overall reactivity effect due to coolant mass flow rate reduction or to total power increase is negative, there is a strong axial variation in the reactivity effect of coolant density change - from large negative effect at the lower part of the seed to a positive effect at the upper part of the seed. Such a wavy behavior of the axial dependent reactivity effect of coolant voiding may induce unstable axial power oscillations and may pose a feasibility issue.

Additional $\mathrm{R} \& \mathrm{D}$ is required in order to arrive at a reliable practical and safe design of a self-sustaining boiling water reactor that uses thorium for the primary fertile fuel. The infrastructure for recycling thorium-based fuel will also have to be developed.

\section{Acknowledgments}

This work was supported by the Berkeley Nuclear Research Center, by a postdoctoral fellowship for F. Arias from the Science and Culture Ministry of Spain-Fulbright fellowship and by the U.S. DOE NEUP program. Contributions of Jeff Seifried of UC Berkeley are also acknowledged.

\section{Conflict of Interest}

The authors declare no conflict of interest.

\section{References}

1. Takeda, R.; Miwa, J.; Maiya, K. BWRs for Long-Term Energy Supply and for Fissioning almost all Transuranium. In GLOBAL 2007: Advances in Nuclear Fuel Cycles and Systems, Boise, Idaho, USA, 9-13 September 2007; pp. 1725-1732.

2. Downar, T.; Hall, A.; Jabaay, D.; Ward, A.; Greenspan, E.; Ganda, F.; Bartoloni, F.; Bergmann, R.; Varela, C.; DiSanzo, C.; Kazimi, M.; et al. Technical Evaluation of the HITACHI Resource-Renewable BWR (RBWR) Design Concept, Final Report; Electric Power Research Institute Report number 1025086; EPRI: Palo-Alto, CA, USA, April 2012.

3. Ganda, F.; Vujic, J.; Greenspan, E. Thorium Self-Sustaining BWR Cores. Presented at the 3rd International Symposium on Innovative Nuclear Energy Systems, INES-3, Tokyo, Japan, 31 November-3 October 2010.

4. Ganda, F.; Vujic, J.; Greenspan, E. Thorium Self Sustaining BWR Cores. In Proceedings of the ICAPP'11, Nice, France, 2-5 May 2011.

5. Atherton, R. Light Water Reactor Breeder Program Summary Report; Report WAPD-TM-1600; Bettis Atomic Power Laboratory: Pittsburgh, PA, USA, October 1987.

6. Ronen, Y. High Converting Water Reactors; CRC Press: Boca Raton, FL, USA, 1990.

7. Radkowsky, A.; Galperin, A. The nonproliferative light water thorium reactor: A new approach to light water reactor core technology. Nucl. Technol. 1998, 124, 215-222. 
8. Galperin, A.; Segev, M.; Todosow, M. A pressurized water reactor plutonium incinerator based on thorium fuel and seed-blanket assembly geometry. Nucl. Technol. 2000, 132, 214-226.

9. Kim, T.K.; Downar, T.J. Thorium fuel performance in a tight-pitch light water reactor lattice. Nucl. Technol. 2002, 138, 17-29.

10. Todosow, M.; Galperin, A.; Herring, S.; Kazimi, M.; Downar, T.; Morozov, A. Use of thorium in light water reactors. Nucl. Technol. 2005, 151, 168-176.

11. Takaki, N.; Permana, S.; Sekimoto, H. Feasibility of Water Cooled Thorium Breeder Reactor Based on LWR Technology. In GLOBAL 2007: Advances in Nuclear Fuel Cycles and Systems, Boise, Idaho, USA, 9-13 September 2007; pp. 1733-1738.

12. Volaski, D.; Fridman, E.; Shwageraus, E. Thermal Design Feasibility of Th- ${ }^{233} \mathrm{U}$ PWR Breeder. In Proceedings of the Global 2009, Paris, France, 6-11 September 2009; Paper 9248.

13. Raitses, G.; Todosow, M. Thorium-Based Fuel Cycle Options For PWRs. In Proceedings of the ICAPP'10, San Diego, CA, USA, 13-17 June 2010; Paper 10305.

14. Ganda, F.; Greenspan, E. Analysis of reactivity coefficients of hydride fuelled PWR cores. Nucl. Sci. Eng. 2010, 164, 1-32.

15. Seifried, J.; Greenspan, E. University of California, Berkeley, CA, USA. Personal communication, July 2012.

(C) 2012 by the authors; licensee MDPI, Basel, Switzerland. This article is an open access article distributed under the terms and conditions of the Creative Commons Attribution license (http://creativecommons.org/licenses/by/3.0/). 